Journal of Financial Economics 00 (0000) 000-000

\title{
Financial expertise of directors
}

\author{
A. Burak Güner ${ }^{\mathrm{a}}$, Ulrike Malmendier ${ }^{\mathrm{b}^{*}}$, Geoffrey Tate $^{\mathrm{c}}$ \\ ${ }^{a}$ Barclays Global Investors, San Francisco, CA 94105, USA \\ ${ }^{b}$ University of California, Berkeley, Berkeley, CA, 94720, USA \\ ${ }^{c}$ University of California at Los Angeles, Los Angeles, CA, 90095, USA
}

Received 28 April 2006; received in revised format 20 May 2007; accepted 24 May 2007

\begin{abstract}
We analyze how directors with financial expertise affect corporate decisions. Using a novel panel data set, we find that financial experts exert significant influence, though not necessarily in the interest of shareholders. When commercial bankers join boards, external funding increases and investment-cash flow sensitivity decreases. However, the increased financing flows to firms with good credit but poor investment opportunities. Similarly, investment bankers on boards are associated with larger bond issues but worse acquisitions. We find little evidence that financial experts affect compensation policy. The results suggest that mandating financial expertise on boards may not benefit shareholders if conflicting interests (e.g., bank profits) are neglected.
\end{abstract}

JEL classifications: G21, G24, G32, G34, G38

Keywords: Corporate Governance, Board of Directors, Board Composition, Finance Experts, Sarbanes-Oxley, Agency Conflicts

We thank Alexander Ljungqvist, Ernst Maug, Stefan Nagel and Philip Strahan for helpful comments. We also thank the seminar audiences at the NBER Summer Institute Corporate Governance meeting, WFA meeting, Fall 2004 NBER Corporate Finance program meeting, the University of Pennsylvania, Stanford, Cornell, University of Notre Dame, UC Irvine, Emory University, UT Austin, Columbia University, USC and University of North Carolina. Justin Fernandez, George Georgiev, Vaibhav Gupta, Nicole Hammer, Rumit Kanakia, Jared Katseff, Catherine Leung, Chenkay Li, Scott McLin, Felix Momsen, Neeraj Shah, $\mathrm{Ning} \mathrm{Xu}$, and Nancy $\mathrm{Yu}$ provided excellent research assistance. Earlier versions of this paper were titled "The Impact of Boards with Financial Expertise on Corporate Policies."

*Corresponding author contact information: ulrike@econ.berkeley.edu

000-000X/00/ \$ see front matter $\subset$ 0000Published by Elsevier Science B.V. All rights reserved 


\section{Introduction}

Much of the corporate governance debate revolves around the composition of corporate boards. Which types of directors can be expected to serve the interests of shareholders? Following the recent wave of accounting scandals, regulators have stressed the need for more financial experts on boards. The implicit assumption is that "an understanding of generally accepted accounting principles and financial statements" will lead to better board oversight and hence will better serve the interest of shareholders. ${ }^{1}$

Financial experts, however, might affect firm policies beyond more accurate disclosure and better audit committee performance. Directors spend a significant portion of their time advising rather than monitoring (Adams and Ferreira, 2007). The advisory influence can be problematic if directors are affiliated with financial institutions and pursue the interests of those institutions rather than maximizing shareholder value. Affiliation with financial institutions has raised concerns in several areas of financial intermediation, such as analyst recommendations and IPO allocations (Malmendier and Shanthikumar, 2007; Reuter, 2006). Nevertheless, recent regulatory efforts to increase financial expertise on boards do not preclude such conflicts. As Sarbanes-Oxley (SOX) enacts a very broad definition of financial expertise, ${ }^{2}$ bankers remain a common type of financial expert on corporate boards. ${ }^{3}$

In this paper we ask whether directors with financial expertise influence corporate policies and whether affiliation hampers their advisory role. We analyze both internal investment (capital expenditures) and external investment (mergers and acquisitions) using a novel data set on the board composition of 282 companies over 14 years.

Our analysis proceeds in three steps. First, we study the impact of financial experts, especially commercial bankers, on internal investment and on the financing of in-

\footnotetext{
${ }^{1}$ See Section 407 of the 2002 Sarbanes-Oxley Act (definition of audit committee financial experts). Similarly, all major stock exchanges have introduced listing requirements on director financial literacy. See also the governance survey by Jensen, Murphy, and Wruck (2004), e.g., recommendation R-36.

${ }^{2}$ The original SOX proposal had a more restrictive definition of financial expert, which would have only included CPAs and people with direct accounting experience. The objection from the business community (e.g., "Blue Ribbon Commissions"), which led to the broadening of the definition, was that the pool of experts is too small, especially if bankers were to be excluded (Tenorio, 2003; Stuart, 2005). In our sample, accountants make up only $0.5 \%$ of directors. CFOs make up $1 \%$.

${ }^{3}$ According to CFO Magazine's analysis (Stuart, 2005), roughly 30\% of boards (among the Fortune 100) identified a director who is "an evaluator of financial statements, such as a banker or investor," an executive who merely supervised the finance or accounting function, or a director with "no discernible professional experience in finance" as their financial expert for the purpose of compliance with SOX.
} 
vestment with bank loans. One hypothesis is that, if firms are financially constrained due to information asymmetries (Myers and Majluf, 1984; Fazzari, Hubbard, and Petersen, 1988), bankers enable firms to finance value-creating projects they would otherwise forgo. In this case, bankers decrease the sensitivity of investment to the availability of internal funds. ${ }^{4}$ An alternative hypothesis is that bankers provide loans even when it is not in the interest of shareholders. Lending to unconstrained firms with low default risk even if they have no value-creating projects - may increase bank profits. Further, it may enable empire-building or overconfident managers (Jensen and Meckling, 1976; Jensen, 1986; Malmendier and Tate, 2005) to divert funds or to overinvest. Such arrangements are more likely if the lending bank is represented on the board so that the board is unlikely to intervene. In this case, investment-cash flow sensitivity also decreases, but mostly in financially unconstrained firms.

We test these hypotheses empirically. We find that when commercial bankers join the board of a firm, the firm displays less investment-cash flow sensitivity and obtains larger loans. The effect depends on affiliation, i.e., the presence of directors whose banks have a lending relationship with the firm. However, lending increases only for firms that are least financially constrained, such as firms with investment-grade debt. These firms also appear to have worse investment opportunities and lower profitability. Constrained firms, instead, receive no such assistance. Thus, the additional lending appears to benefit creditors rather than shareholders. We find no measurable impact of other, unconflicted financial experts.

Second, we consider external investment (i.e., mergers and acquisitions) and financing with public securities. Here, we focus on investment bankers. We find that firms with investment bankers on their boards undertake worse acquisitions. In the five days around takeover bids, such firms lose 1\% more than firms without investment banker directors. They also lose significantly more value over the three years following an acquisition. Firms with investment bankers on their board are also associated with larger bond issues, particularly if the director's bank is involved in the deal. And, while investment bankers on the board generally seem to reduce underwriting fees, this helping hand is not

\footnotetext{
${ }^{4}$ Consistent with this story, Hoshi, Kashyap, and Scharfstein (1991) find that investment is less sensitive to cash flow in Japanese firms with keiretsu membership. Ramirez (1995) finds that firms with J.P. Morgan executives on their boards displayed lower investment-cash flow sensitivity at the turn of the $20^{\text {th }}$ century.
} 
visible when their own bank is involved in the deal. Thus, like commercial bankers, investment bankers have a significant impact on corporate decisions, but not necessarily in the interest of shareholders. Again, there is little evidence that nonconflicted financial experts improve firm policies (or have any impact at all).

Third, we test for the influence of financial experts on decisions in which their outside incentives are not in conflict with the interests of shareholders, such as CEO compensation. ${ }^{5}$ We find little evidence that financial experts affect decisions without clear consequences for their home institutions.

Our results challenge the view that more financial expertise on corporate boards unambiguously improves firm policy. Rather, the benefits have to be weighted against the costs due to misaligned incentives. Financial experts are associated with policies that may create value for their financial institutions, but not necessarily for shareholders. Our findings do not imply, however, that financial experts destroy shareholder value on net. Companies may benefit from financial expertise on their board through other avenues. For example, Agrawal and Chadha (2005) find that having directors with a CPA, CFA, or similar degree on audit committees translates into fewer earnings restatements, and DeFond, Hann, and $\mathrm{Hu}$ (2005) document a positive stock market reaction to the appointment of directors with accounting knowledge to the audit committee (though not to the appointment of other financial experts). Moreover, our data consist of large, mature U.S. firms; small early-stage firms may benefit from the financial expertise of venture capitalists (Hellmann and Puri, 2002; Kortum and Lerner, 2000).

A key concern for any analysis of director effects is the endogeneity of board composition, a point made both theoretically and empirically by Hermalin and Weisbach (1988, 1998), among others. ${ }^{6}$ In particular, the causality may be reverse, and firms' financing needs may determine the board representation of financial institutions. ${ }^{7}$ Our detailed data allow us to better address these concerns for several reasons.

First, the 14-year time series provides sufficient variation in board composition to

\footnotetext{
${ }^{5}$ For a discussion on the role of directors in setting compensation and of financial expertise (e.g., in understanding the value of option grants that are not expensed), see Holmström and Kaplan (2003).

${ }^{6}$ For an extensive review of the literature see Hermalin and Weisbach (2003).

${ }^{7}$ Stearns and Mizruchi (1993), Pfeffer (1992), and Booth and Deli (1999) interpret the correlation between firm leverage and the presence of bankers on a board as evidence of firms hiring directors for their debt market expertise.
} 
identify commercial banker effects even after controlling for company fixed effects. Thus, the estimated effect does not reflect time-invariant firm characteristics.

Second, we are able to instrument for the presence of commercial bankers on boards using pre-sample shocks to the supply of banker directors. During the banking crisis in the late 1970s and early 1980s, executives of commercial banks became less suitable candidates for corporate boards. As a result, open board positions between 1976 and 1985 were less likely to be filled with commercial bankers than in other decades, while the overall rate of board appointments remained the same. We instrument for the number of commercial bankers on the board with the number of current directors hired during the crisis period. All results replicate. A placebo instrument, the number of directors appointed between 1966 and 1975, fails to replicate the results, corroborating our analysis.

Finally, we can identify and remove company-year observations in which selection concerns are most severe, such as years with major acquisitions and the first years of a banker's tenure. We show that such years do not drive our results.

For other financial experts, we cannot use fixed effects in most cases. For example, there is insufficient within-firm variation in acquisitions to identify the investment banker effect. We also do not have an instrumental variable strategy. As in previous literature, we rely on cross-sectional identification and must be cautious about the interpretation of the findings. The endogeneity concerns are ameliorated, though, by the discrepancy between high frequency corporate decisions and low frequency board turnover. (Average director tenure is nine years.) Costs of termination and search costs make it impractical to adjust board composition for every policy. Thus, even if a director is chosen to implement a specific policy, firms must consider many policy dimensions. For example, a director hired for her debt market expertise will also influence executive compensation and acquisition policies, but her impact on the latter decisions may conflict with the preferences of the CEO or the shareholders.

Our analysis complements a growing literature relating board characteristics to firm performance (Fich and Shivdasani, 2006; Perry and Peyer, 2005) and extends the analysis to specific corporate policies. Kroszner and Strahan (2001a, 2001b) also study conflicts of interest when commercial bankers sit on corporate boards. They find that banker directors are less common in smaller, more volatile firms, where conflicts are 
most severe, and in distressed firms, where legal constraints such as equitable subordination deter bankers. Our results indicate that conflicts of interest still matter in large, stable firms. Consistent with this interpretation, Kracaw and Zenner (1998) find a negative stock price reaction to bank loans if an affiliate of the lending bank sits on the board of the borrower. Morck and Nakamura (1999) show that banker directors emphasize policies that favor creditors over shareholders in a data set on Japanese bank ties.

The remainder of the paper is organized as follows. In Section 2, we describe the data. In Section 3, we investigate the effect of financial expertise on internal investment and financing policies. We study acquisition and public issuance decisions in Section 4, and in Section 5 we evaluate the impact of financial expertise on policies which preclude conflicts of interests. Finally, in Section 6, we conclude.

\section{Data}

We analyze a sample of publicly traded companies from 1988 to $2001{ }^{8}$ We build on the data set of Hall and Liebman (1998) and Yermack (1995), merged with CEO demographics from Malmendier and Tate (2005). To be included in the original HallLiebman sample, a firm has to appear at least four times on one of the lists of largest US companies published by Forbes magazine from 1984 to 1994. We exclude financial firms.

We hand-collect biographical information on all board members of these companies using annual proxy statements (1988-1997) and the IRRC database (1998-2001). We code each outside director's main employment into one of the following categories: ${ }^{9}$ (1) commercial bank executive, (2) investment bank executive, (3) executive of a nonbank financial institution, (4) finance executive (CFO, Accountant, Treasurer, or Vice President for Finance), (5) "finance" professor (including finance, economics, accounting, and business), (6) consultant, (7) lawyer, (8) executive of a nonfinancial firm that

\footnotetext{
${ }^{8}$ Our sample period excludes SOX-induced changes. The homogeneity of the pre-SOX data allows us to exploit the full time series for the estimation of financial expert effects. Evaluating the impact of SOX is currently infeasible since our estimations would require multiple post-SOX observations (after the extended compliance deadlines in 2005).

${ }^{9}$ The employee falls into more than one category in a few cases, such as when the employee's bank offers both category (1) and category (2) services.
} 
falls outside these categories, and (9) noncorporate worker (including careers in academia, nonprofit or civil activist organizations, and politics).

We take additional steps to refine the first two categories, which play a key role in the analysis. First, if the description of a banker's employer is vague or missing, we identify the bank from the FDIC list of U.S. chartered commercial banks and the Carter-Manaster IPO underwriter reputation rankings updated by Loughran and Ritter (2004). To be considered a banker, the director has to be an executive of the bank, not just a board member of the bank. The exception is when the director retains a seat on the bank's board upon retiring from an executive position. However, retired bankers who do not retain a seat on the bank's board are reclassified in category (8) since they should no longer be affected by misaligned incentives. ${ }^{10} \mathrm{We}$ do the same for retired executives of non-bank financial institutions. To the extent that the reclassification into the nonbanker sample is an "overadjustment," the resulting measurement error works against finding significant effects in our regression analysis. We classify retired directors of categories (4) to (9) into the category most in line with their pre-retirement work history.

The data collection yields 32,943 observations. The summary statistics are in Table 1, Panel A. Insiders, i.e., current or former employees of the firm or relatives of executives, make up $27 \%$ of director-years. Outsiders from nonfinancial industries account for $44 \%$ and directors in noncorporate careers for $10 \%$ of director-years. Financial experts account for $18 \%$ of director-years, with executives of nonbank financial firms the most common (8\%) and accountants the least $(0.5 \%)$. Directors are on average 60 years old, have served on the board for nine years, and hold two other directorships. Women account for only $8.5 \%$ of director-years.

We transform the sample into firm-years in Panel B. The panel shows that $27 \%$ of the firm-years have a director from a commercial bank, and $16 \%$ a director from an investment bank. We denote a commercial banker as affiliated if her bank has lent to the firm in the past, as reported in the Dealscan database; $22 \%$ of the commercial bankeryears involve an affiliated banker. Financial executives and accountants are present in almost half of the firm-years (46\%) and academics with a financial economics back-

\footnotetext{
${ }^{10}$ In a small number of cases (particularly in the IRRC data), we know that the director is retired, but we know nothing about her past employment. These directors are classified in category (8).
} 
ground in $18 \%$. Finally, $56 \%$ of firm-years contain a director who is an executive of a nonbank financial company.

We supplement the director data with accounting and financial information from COMPUSTAT. The resulting sample contains 2,910 firm-year observations corresponding to 282 different firms. We measure capital as property, plants, and equipment (item 8), investment as capital expenditures (item 128), and cash flow as earnings before extraordinary items (item 18) plus depreciation (item 14). The latter variable is key to the first part of our analysis. It captures how much operating cash a firm generates in a given year. ${ }^{11}$ We normalize investment and cash flow by lagged capital. ${ }^{12}$ Tobin's $Q$ is the market value of assets normalized by total assets (item 6), where the market value is total assets plus market equity (item 25 multiplied by item 199) minus book equity. Book equity is equal to total assets minus liabilities (item 181) minus preferred stock liquidating value (item 10) plus balance sheet deferred taxes and investment tax credit (item 35) plus convertible debt (item 79). If this computation yields no result, we measure book equity as item 60. Return on assets (ROA) is income divided by the average of current and lagged total assets, where income is earnings before extraordinary items (item 18) plus interest expense (item 15) plus income statement deferred taxes (data 50), when nonmissing, plus investment tax credit (data 51), when nonmissing. Return on equity (ROE) is net income (item 172) scaled by the average of current and lagged book equity. ${ }^{13}$ Altman's (1968) zscore, as modified by MacKie-Mason (1990), is defined as 3.3 times the difference in operating income before depreciation (item 13) and depreciation and amortization (item 14) plus sales (item 12) plus 1.4 times retained earnings (item 36) plus 1.2 times working capital (data 121), divided by total assets (item 6). Book leverage is long-term debt (item 9) plus debt in current liabilities (item 34), divided by long-term debt plus debt in current liabilities plus stockholders' equity (item 216). Market leverage is long-term debt plus debt in current liabilities, divided by the market value of assets. Board size is the number

\footnotetext{
${ }^{11}$ We use the standard definition of cash flow in the investment-cash flow literature (e.g., Fazzari, Hubbard, and Peterson, 1988; Kaplan and Zingales, 1997). The capital structure literature accounts, instead, for changes in working capital, though in a different context: in order to calculate the required amount of external financing, cash flow (defined similarly) is subtracted from the sum of changes in working capital, investment, and dividends. (See, e.g., Frank and Goyal, 2003).

${ }^{12}$ Cash flow normalized by capital contains a few extreme values. To avoid the confounding effect of outliers on our results, we trim the sample at the $1 \%$ level.

${ }^{13}$ Because of extreme outliers, we trim ROE at the $1 \%$ level. Winsorizing yields similar results.
} 
of directors. Board independence is the number of outside directors scaled by board size. Finally, Panel C shows the distribution across the 17 Fama-French industries.

We also split the sample into firms with and without financial experts on their board, separately for each type of expert. ${ }^{14}$ Comparing the subsamples with and without commercial bankers, we find that firms with commercial bankers on their board are larger (in terms of assets), though not significantly so. They also appear to generate more cash flow and to invest more, but the pattern reverses once we normalize by lagged capital. Interestingly, both average Q and z-score are higher in the sample without bankers, and ROA and ROE are not significantly different, nor are market and book leverage. Thus, the summary statistics fail to reveal a systematic pattern of higher profitability or better access to capital markets for firms with commercial bankers, as a sorting argument would suggest. The pattern is more consistent for the subsamples with and without investment bankers. Firms with investment bankers are larger, have higher investment volume and cash flow (even after normalization), and a higher Q, though all differences but one are insignificant. ROA and ROE are, again, virtually identical. For the subsamples with and without finance executives and accountants, the pattern reverses. Size, investment, cash flow, and Q are larger in the subsamples without these types of financial experts. The pattern is similar for the subsamples with and without executives of nonbank financial companies and the subsamples with and without finance professors. The most robust finding is that average ROA and ROE are virtually identical across all sample splits.

The sample differences reveal nonrandom sorting of finance experts, though not always according to the traditional sorting story (i.e., into more profitable and less constrained firms). The endogeneity underscores the importance of a panel analysis, including fixed effects, and, where possible, instrumenting for the presence of experts on a board.

We supplement our sample with data from CRSP (monthly stock returns), Execucomp (CEO compensation), I/B/E/S (analyst coverage), SDC (public debt and equity issues, and acquisitions), and the Loan Pricing Corporation's Dealscan (bank loans).

\section{Internal investment and loan financing}

\footnotetext{
14 Tables with the summary statistics of all subsamples and significance tests are available from the authors. All tests of significant differences in means use standard errors that are clustered at the firm level.
} 
The core question of this paper is whether board members with financial expertise affect corporate policies and, if so, whether affiliation distorts their impact.

\subsection{Sensitivity of investment to cash flow}

We begin our analysis by investigating the impact of finance experts on internal investment and financing decisions. We estimate the standard model of internal investment:

$$
\begin{aligned}
I_{i t}= & \alpha+\beta_{1} C F_{i t}+\beta^{\prime}{ }_{2} F I N_{i t}+\beta^{\prime}{ }_{3} F_{I N} * C F_{i t} \\
& +\beta_{4} Q_{i t-1}+\beta_{5} Q_{i t-1} * C F_{i t}+\beta^{\prime}{ }_{6} X_{i t}+\beta^{\prime}{ }_{7} X_{i t} * C F_{i t}+\varepsilon_{i t .} .
\end{aligned}
$$

The above model determines investment as a function of firm and board characteristics. Specifically, $C F$ is cash flow, FIN is the set of dummies for finance experts, $Q$ is Tobin's $\mathrm{Q}$, and $X$ is an array of other controls, including the natural logarithms of firm and board size, the fraction of outside directors, and fixed effects for year, S\&P long-term debt rating, and firm or industry. Industries are the Fama and French 48 industry groups. We test for the significance of $\beta_{3}$. To correct for heteroskedasticity and correlation of errors within firms, we cluster standard errors at the firm level. ${ }^{15}$ This adjustment makes a substantial difference given the slow evolution of board composition and autocorrelation in capital expenditures.

Column I of Table 2 presents the baseline regression without banker indicators. As in prior studies, both cash flow and Q positively predict investment. The ratio of outside directors is negatively related to investment. Column II includes the dummies for financial experts. The cash flow, Q, and board independence coefficients vary little, and none of the financial expert dummies are significant. The interaction of commercial banker and cash flow, however, has a negative coefficient that is statistically significant at the $1 \%$ level. It is also economically significant: baseline investment-cash flow sensitivity, evaluated at the mean of the continuous explanatory variables, with all expertise variables at zero, and for the baseline year (1988), industry (agriculture), and S\&P credit rating (none), is $\$ 0.36$. Adding a commercial banker to the board decreases this sensitivity by $33 \%$, or $\$ 0.12$. For other finance experts, the coefficient estimates on the interaction terms are insignificant and much smaller in magnitude. All results are robust to

\footnotetext{
${ }^{15}$ We cluster standard errors throughout the paper, even where it is not explicitly noted in the text.
} 
variations in the financial expert variables such as using fractions or counts instead of dummies. Thus, the presence of commercial bankers is associated with lower investmentcash flow sensitivity, but none of the other types of financial experts appear to matter.

The main difficulty in interpreting these findings is unobserved firm heterogeneity. One interpretation is that commercial bankers induce lower investment-cash flow sensitivity. An alternative interpretation is that firms with low investment-cash flow sensitivity seek bankers as directors. Or, bankers may decline directorships in firms that are investment-cash flow sensitive. The latter is particularly plausible if firms with higher investment-cash flow sensitivity are in financial distress. In these firms, the legal principles of equitable subordination and lender liability may deter a lending bank from board representation since involvement in active management impairs the bank's claims in case of bankruptcy (Kroszner and Strahan, 2001a). ${ }^{16}$

The latter interpretation is implausible in our data since the legal constraints apply only in the case of bankruptcy. Bankruptcy is unlikely for our sample firms as indicated, for example, by the 2.05 average $z$-score (and 1.93 median). ${ }^{17}$ Moreover, the average $\mathrm{z}$ score is even higher in firms without commercial bankers (2.14) than in those with commercial bankers (1.81). The broader selection concern, however, remains, and we take several steps to address it.

First, we exploit within-firm variation in the presence of bankers on the board. In 55 cases, the COMBANKER dummy variable changes from zero to one, and in 93 cases from one to zero. The value of COMBANKER shows time-series variation in 104 out of 282 firms. In Column III, we add firm fixed effects, and in Column IV we also include interactions of the firm effects with cash flow. The decrease in cash flow sensitivity among larger firms now becomes significant. The negative effect of COMBANKER on cash flow sensitivity is diminished in magnitude and precision though still significant at the $5 \%$ and $10 \%$ level, respectively. As we will see in Section 3.2, the reduced effect is due to constrained firms in which commercial bankers do little to influence firm policy. The positive effect of COMBANKER on investment also becomes significant. The posi-

\footnotetext{
${ }^{16}$ Board representation is not sufficient for such impairment; see Sprayregen, Friedland, and Mayer (2003) and Douglas (2003).

${ }^{17}$ We report the modified z-score of MacKie-Mason (1990). Using the formula from Altman (1968), the overall sample mean is 3.74 and falls well within the "safe zone" (cutoff $=3$ ). The scores for firms with and without commercial bankers are 3.07 and 3.98 , respectively.
} 
tive level effect combines with the negative sensitivity to produce an overall increase of $2.5 \%$ (Column III) and 5\% (Column IV) from the mean of capital-scaled investment.

The robustness of our findings to the inclusion of firm fixed effects leaves two possible interpretations. Either commercial bankers on the board reduce the sensitivity of investment to internal funds, or the results reflect time-varying firm characteristics. Under the latter interpretation, firms ask bankers to join boards precisely when they are seeking external financing and to depart when scaling back investment. And bankers agree to join boards only if and as long as they foresee a profitable financing opportunity.

Before we address this alternative explanation directly, we note that the low degree of within-firm variation in board size undermines its plausibility. Investment and financing vary a lot within firms, but board size remains constant from one year to the next in $45 \%$ of all firm-years. The median year-over-year change in board size is zero; the mean change is -0.102 (with a standard deviation of 1.296). Fig. 1 shows that mean and median board size are, if anything, decreasing over our sample period. Moreover, director tenure is long, with a mean of nine years. Thus, the turnover of directors appears too low and "out of sync" with high frequency corporate decisions to represent task- or policyspecific entry and exit. If directors are hired to implement specific policy changes, then most of their time on the board is likely to occur after those policies are in effect.

Nevertheless, we address this concern in several ways. If directors are hired to help implement a specific firm policy, their impact should be mainly felt in their first one or two years on the board. Thus, as a first robustness check, we recode the COMBANKER dummy as zero in those years. Replicating Table 2, we find very similar results. For example, removing the first two years of a banker's board tenure, we find cash flow sensitivities of $-0.121,-0.084$, and -0.054 in the three specifications of Columns II, III, and IV, respectively, with significance at the $1 \%, 5 \%$, and $10 \%$ levels. Second, we identify years with major policy changes that are possible candidates for selective board appointments. Specifically, we remove the three years around major acquisitions with transaction values of at least $15 \%$ of the market value of the acquirer's assets. Our results are again qualita- 
tively unchanged. ${ }^{18}$ These robustness checks suggest that timed director selection is unlikely to drive the estimated banker effect.

Finally, we instrument for the board presence of commercial bankers. We exploit the commercial banking crisis of the late 1970s and early 1980s as a source of exogenous variation in board composition. When legislative changes during the 1970s and 1980s allowed greater competition in the banking industry, banks raised interest rates on demand deposits, inducing greater risk taking on the asset side of their balance sheets. Many of these risks failed to pay off. The sovereign debt crises in developing countries like Brazil, Mexico, and Argentina and the end of the real estate boom in the 1980s eroded bank profitability. Beginning in the second half of the 1970s and continuing through the 1980s, the commercial banking industry went into crisis. The frequency of bank failure exploded (Park, 1994). As executives of failed commercial banks exited the potential director pool, the number of commercial bankers available to firms appointing new directors declined. As a result, firms that happened to appoint more directors during the 1976-1985 decade are likely to have fewer commercial bankers serving on the board. Thus, our instrument for the number of commercial bankers serving on the board is the number of current directors who were appointed between 1976 and 1985.

The validity of the instrument relies on the assumption that board turnover between 1976 and 1985 is not different from other periods. If firms hired at a higher or lower rate during the crisis period, then the same shock that precipitated board restructuring during the crisis period might explain changes in investment during the sample period. We find, however, that the year-over-year distribution of directors' tenure is stable. In every single year, the median is seven years. In addition, the $25^{\text {th }}$ and $10^{\text {th }}$ percentiles of the tenure distribution are identical in all sample years, and the $75^{\text {th }}$ and $90^{\text {th }}$ percentiles vary at most by one year in either direction.

Another potential concern about the instrument is that it captures variation in director tenure across firms. For example, well-run firms may have low board turnover, resulting in both low values of the instrument and low investment-cash flow sensitivity. We address this concern directly by including mean board tenure and its interaction with cash

\footnotetext{
${ }^{18}$ Table available from the authors. We also check directly how frequently major acquisitions lead to board restructuring. We find only six cases of bankers entering or exiting in the three years around the acquisitions.
} 
flow in our regressions. ${ }^{19} \mathrm{We}$ also account for industry-specific patterns in board restructuring and investment-cash flow sensitivity by including dummies for the 48 FamaFrench industry groups and their interactions with cash flow. These controls address, for example, responses to industry-specific takeover pressure. ${ }^{20}$ Since our instrument exploits variation in board appointments across firms, we cannot include firm fixed effects.

It is important to acknowledge remaining concerns about excludability of the instrument from the investment regression. Ideally, firms would be differently affected by the banking crisis only through the channel of director selection. The banking crisis does not provide such a clean experiment. Director appointments between 1976 and 1985, however, are unlikely to affect investment during our later 1988-2001 sample period.

In Table 3, we present the results of two-stage least squares regressions. As with board size, we use the natural logarithms of one plus the number of current directors appointed in 1976-1985 (CRISIS) and one plus the number of commercial bankers on the board (\#COMBANKER). CRISIS and the interaction of CRISIS with cash flow instrument for the number of commercial bankers and its interaction with cash flow. ${ }^{21}$ We do not include other financial experts, since their estimated impacts were consistently small and insignificant and we do not have appropriate instruments. Column I replicates the baseline regression using the number of commercial bankers rather than our earlier indicator variable. In Columns II and III, we report the first-stage regressions of the number of commercial bankers and its cash flow interaction on CRISIS and the interaction of CRISIS with cash flow. The instruments are correlated with the variables for which they instrument. Wald tests reject, at the $1 \%$ level, the hypothesis that the coefficients on CRISIS

\footnotetext{
${ }^{19}$ Another way to address this concern is to add controls for firm governance and its interaction with cash flow. We reestimate our regressions adding the number of outsiders on the board as a control and find little impact on the results. We also add age and its interaction with cash flow since the definition of CRISIS places restrictions on directors' age. The results are unaffected. Finally, the results are robust to interacting tenure with age and, in turn, with cash flow. This addresses the concern that not only long tenure, but also being young and active, affects director effectiveness (and might be captured by the CRISIS variable).

Another concern might be that the tenure control variable is skewed given the low rate of board turnover. We find, however, that mean board tenure exhibits little skewness, with a mean of 9.82, a median of 9.25, and a standard deviation of 3.91. Moreover, the results of the regression in Table 4 become slightly stronger when using median tenure (and age) and are robust to including quadratic terms in median tenure and age and their interactions with cash flow.

${ }^{20} \mathrm{We}$ also address the concern about takeover pressure directly and reestimate the model starting in 1990 (after the takeover pressure largely subsided). We find similar results.

${ }^{21}$ We use the number of bankers (rather than the dummy) in the instrument regressions, since a binary endogenous variable would induce nonclassical measurement error.
} 
and $(C R I S I S) *(C F)$ are jointly equal to zero. Column IV shows the investment model after instrumenting for \#COMBANKER and its cash flow interaction. As in the baseline regression in Column I, Q is positively related to investment, while board independence is a negative predictor of investment but a positive predictor of investment-cash flow sensitivity. The estimated effect of board tenure remains small and marginally significant with the opposite pattern: a positive effect on investment and a negative effect on its cash flow sensitivity. The level effect of \#COMBANKER loses its significance. Most importantly,

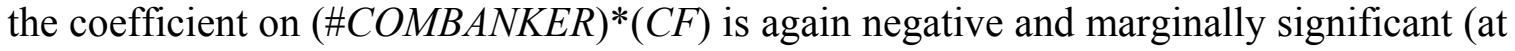
the $10 \%$ level). Evaluated at the mean and for the baseline year (1988), industry (agriculture), and S\&P credit rating (none), investment increases by $\$ 0.41$ for each dollar of cash flow. Adding a standard deviation of commercial banker presence to the board decreases this sensitivity by 30 cents, meaning that $\$ 1$ of cash flow increases investment by only $\$ 0.11$.

As a placebo test, we repeat the two-stage least squares regressions using directors appointed between 1966 and 1975 in lieu of the instrument. Since this era pre-dated the commercial banking crisis, the results should not replicate. Indeed, we find that both the first and the second stages fail. This uniqueness strengthens the argument that the CRISIS variables matter because of the proposed banking crisis channel and enhances the validity of our instrument. Moreover, the placebo instrument provides direct evidence that CRISIS does not simply capture the effect of "stable and long-lasting directorship."

We conclude that commercial bankers significantly reduce companies' sensitivity of investment to internal resources. We detect no such impact for other financial experts.

\subsection{Is less investment-cash flow sensitivity more efficient?}

We now ask whether the impact of bankers on investment benefits shareholders. We also explore the channel of the bankers' influence.

The reduction in investment-cash flow sensitivity is open to different interpretations. If investment-cash flow sensitivity reflects capital market imperfections, then bankers mitigate financing frictions. Their boardroom presence may, for example, reduce information asymmetries and facilitate financing for valuable projects. If, instead, investment-cash flow sensitivity is due to a managerial propensity to overinvest out of free cash flow, bankers may increase value by acting as monitors and inducing firms to cut 
(over-)investment when internal cash flow is high. On the other hand, bankers might destroy value by providing additional funds to managers and allowing them to overinvest when cash flow is low. The latter story is plausible since bankers have little incentive to induce efficient investment, given the low shareholdings of U.S. banks relative to their loan volume (Gorton and Winton, 2003). Bankers may back inefficient but low risk projects to benefit their own banks, possibly against the interest of shareholders.

\subsubsection{Financing constraints}

To test these hypotheses, we first examine financial constraints. If the decrease in investment-cash flow sensitivity is the result of better access to external financing and less underinvestment, it should be most prominent when firms are financially constrained.

There is little consensus on the best way to measure financial constraints. We employ several different proxies proposed in previous literature. First, we construct the Kaplan-Zingles (KZ) index for our sample, following standard practice (Lamont, Polk, and Saá-Requejo, 2001; Baker, Stein, and Wurgler, 2003; Malmendier and Tate, 2005). Kaplan and Zingales (1997) argue that simple proxies like firm size and dividend payout do not capture financing constraints. ${ }^{22}$ They measure financial constraints by using both quantitative data (accounting variables) and qualitative data (annual proxies, interviews with managers, etc) and estimate a logit regression of constraints on firm characteristics. We use their estimates to construct an index of financial constraints:

$$
\begin{aligned}
K Z_{i t}= & -1.001909 * \frac{C F_{i t}}{K_{i t-1}}-0.2826389 * Q_{i t}+3.139193 * \text { Leverage }_{i t} \\
& -39.3678 * \frac{\text { Dividends }}{K_{i t-1}}-1.314759 * \frac{C_{i t}}{K_{i t-1}},
\end{aligned}
$$

where $C F$ is cash flow, $K$ capital, $Q$ Tobin's Q, and $C$ cash and short-term investments. Higher $K Z$ values indicate greater financial constraint. We use the sample median of the lagged KZ index to split firm-years into constrained and unconstrained subsamples.

The KZ index is not without shortcomings. In particular, it assumes that the index weights generalize beyond the original sample of manufacturing firms. Using the index to

\footnotetext{
${ }^{22}$ Using model-generated data, Moyen (2004) shows that firms with low dividends - considered to be more financially constrained in several studies - are in fact more likely to be unconstrained.
} 
split the sample, rather than as a continuous measure, mitigates concerns about measurement error. Nevertheless, to check the robustness of our results, we consider three alternative proxies. ${ }^{23}$ First, we use investment-grade long-term debt ratings (BBB and above) as an indicator of smooth access to external capital. ${ }^{24}$ Second, we use the number of analysts following the stock. Third, we use the degree of disagreement among analysts, as measured by the standard deviation of quarterly earnings estimates in the quarter ending before the annual proxy meeting. The last two proxies address the concern that the KZ index and (indirectly) bond ratings may indicate financial distress rather than constraints. Analyst-based proxies more directly capture informational asymmetries as a source of external finance constraints. ${ }^{25}$ The alternative proxies lead to largely similar and sometimes stronger results. ${ }^{26}$ For brevity, we report only the estimates using the KZ index.

Before turning to the split-sample regressions, we compare the subsamples of constrained and unconstrained firm-years and calculate differences in means. All tests of significant differences in means use standard errors that are clustered at the firm level. Interestingly, in the constrained subsample average assets $(\$ 8.8 \mathrm{bn})$, capital $(\$ 4.7 \mathrm{bn})$, and investment (\$0.7bn) are larger than in the unconstrained subsample (\$6.9bn, \$2.1bn, and $\$ 0.4 \mathrm{bn}$, respectively). Cash flow is smaller, though not significantly ( $\$ 0.7 \mathrm{bn}$ versus $\$ 0.8 \mathrm{bn})$. The difference becomes significant and large after normalizing by lagged capital. Book and market leverage are significantly larger in constrained firms. The differences in cash flow and leverage reflect their role in determining the KZ split. The average z-score is significantly lower in the constrained subsample (1.53) than in the unconstrained subsample (2.57) confirming that the $\mathrm{KZ}$ index captures constraints. At the same time, the z-scores illustrate that the difference between "constrained" and "unconstrained" is not to be confused with "financially troubled" and "financially healthy." Both z-scores are significantly different from one at the $1 \%$ level. Thus, bankruptcy considera-

\footnotetext{
${ }^{23}$ An extensive list of classification schemes can be found in Hubbard's (1998) review article.

${ }^{24}$ See, among others, Kashyap, Lamont, and Stein (1994), Calomiris, Himmelberg, and Wachtel (1995), and Hubbard, Kuttner, and Palia (2002). When using credit ratings, we drop firms with no rated debt.

${ }^{25}$ Other papers using analyst coverage or analyst disagreement for financial constraints or informational asymmetry include Chang, Dasgupta, and Hilary (2006) and Ajinkya and Gift (1985).

26 Tables are available upon request.
} 
tions are unlikely to have bite in either subsample. ${ }^{27}$

The summary statistics also speak to the concern that bankers select into unconstrained firms. Commercial bankers are present on the board in $30 \%$ of the constrained subsample and $26 \%$ of the unconstrained sample. There are no significant differences in the presence of any type of financial expert among the two subsamples of constrained and unconstrained firms. This result may reflect the frequency with which firms move between subsamples while bankers appointed to the board remain directors: Out of the 282 firms, 132 make at least one switch from "constrained" to "unconstrained" or vice versa.

Table 4 presents the split-sample regressions. In Columns I and II, we replicate the most stringent specification of Table 2 (Column IV, including firm effects and firmcash flow interactions) for both subsamples. Note that in this specification we cannot easily interpret the coefficient of cash flow, as it depends on which firm dummy we omit from the regression and captures only the sensitivity of that one firm. We find that bankers significantly reduce the sensitivity of investment to cash flow when firms are unconstrained rather than when they are constrained. Also, the positive level effect of COM$B A N K E R$ is present only in the unconstrained subsample. As before, none of the other financial experts exert a significant level or interaction effect.

These results cast doubt on the hypothesis that bankers help to solve information problems between firms and capital markets. In the subset of firms most likely to be affected by informational asymmetries, commercial bankers do not exert significant influence on investment and financing. They only matter in unconstrained firms.

The value consequences of reduced investment-cash flow sensitivity in unconstrained firms, however, remain ambiguous. Commercial bankers may prevent the abuse of funds when cash flow is high. Or, they may provide additional funds to empirebuilding managers when free cash flow is low. In the next Subsection, we analyze lending and lending affiliation to disentangle the different interpretations.

\subsubsection{Lending and lending affiliation}

We start the analysis of bank lending by testing whether banker directors (efficiently) provide additional loans to constrained firms. We also test whether they provide

\footnotetext{
${ }^{27}$ We also use the formula from Altman (1968) to place our firms within the standard "zones of discrimination." In the constrained subsample, the mean Altman's z-score is 2.47 and in the unconstrained sample it is 5.09. Both scores are well above the 1.8 cutoff for the "distress zone."
} 
additional loans to unconstrained firms. Increased lending to unconstrained firms would suggest that commercial bankers reduce sensitivity of investment to cash flow by providing funds when cash flow is low rather than by restricting (over-)investment when cash flow is high. Finally, we test whether the reduction in investment-cash flow sensitivity among unconstrained firms is due to affiliated bankers, whose banks originate loans to the firm. A positive result would directly confirm the importance of the lending mechanism.

We use the Loan Pricing Corporation's Dealscan database to obtain detailed information on loan terms and lenders (see Güner, 2006). Table 5 summarizes the data. We consider a banker-director to be affiliated if her bank is a member of the lending syndicate. Of the 1,288 loans for which loan size is available, 89 are obtained by firms with an affiliated commercial banker on the board (and in 46 of these deals the director's bank acts as a lead manager), 223 are obtained by firms with only unaffiliated commercial bankers, and 976 are obtained by firms without a commercial banker director. The first column of $p$-values (" $p$-value (A-U)") reveals that none of the board composition and other firm variables have significantly different means in the affiliated and unaffiliated samples. Q is insignificantly lower in the affiliated sample $(p=0.15)$, suggestive of worse investment opportunities. The statistics on tranche and spreads suggest that affiliated deals are larger (significant with $p=0.03$ ), but also more expensive (insignificant at $p=0.15$ ). The same is true comparing affiliated deals to deals in firms without commercial bankers on the board. (Here, both differences are significant with $p$-values of 0.03 and 0.05 , respectively.)

To isolate the banker effect, we regress loan size on the presence of bankers, controlling for an array of firm, board, and deal characteristics. The firm and board controls are the logarithm of firm total assets; Tobin's Q; plant, property, and equipment over assets; stock volatility; leverage; log board size; and the ratio of independent directors on the board. The contract controls are designed to capture borrower risk, which in turn affects loan pricing. As in previous literature, ${ }^{28}$ we use the logarithm of the days between contract initiation and maturity, a dummy for origination by a syndicate rather than a sole lender, number of lenders in the syndicate, and indicators for seniority and security of the

\footnotetext{
${ }^{28}$ See, e.g., Kroszner and Strahan (2001b) and Hubbard, Kuttner, and Palia (2002).
} 
loan. (See the Appendix for more details on these variables.) We also include fixed effects for S\&P credit ratings, year, and industry or firm.

Table 6 presents the regression results. Column I shows that commercial bankers on the board are associated with an increase in loan size of $\$ 346.7 \mathrm{~m}$. The coefficient on the investment banker dummy is also positive, though smaller and not significant. The coefficients on all other expertise dummies are much smaller in magnitude and insignificant. Among all firm, board, and deal characteristics, only firm size and the number of lenders are significant (positive). In Column II we test the extent to which affiliated and unaffiliated bankers contribute to the positive effect of commercial bankers on loan size. We estimate a significant coefficient of $\$ 458.4 \mathrm{~m}$ for affiliated bankers and an insignificant coefficient of 295.7 for unaffiliated bankers. The difference is not significantly different from zero ( $p$-value $=0.2273$ ). The size and affiliation effects are larger in magnitude if we include firm fixed effects $(\$ 510 \mathrm{~m}$ and $\$ 643 \mathrm{~m})$, but are insignificant with $p$ values of 0.20 and 0.12 .

In untabulated regressions, we also test whether the effects are stronger when the director's bank is the lead manager of the lending syndicate and thus likely to determine the loan terms. Affiliated LEAD COMBANKER has a coefficient of $\$ 674 \mathrm{~m}$ ( $p$-value $=$ 0.08 ), compared to $\$ 229 \mathrm{~m}$ for Affiliated PARTICIPANT BANK ( $p$-value $=0.094)$, but the difference is again insignificant $(p$-value $=0.283$ ). The results are similar with firm fixed effects.

As in our analysis of investment, we check whether additional lending is directed towards financially constrained or unconstrained firms, using the overall sample median of the KZ index to split the sample. The results are in Columns III-VI of Table 6. We find that the loan increase is largely driven by unconstrained firms. In the model with industry fixed effects and the unconstrained subsample, affiliated loans are on average $\$ 911 \mathrm{~m}$ larger ( $p$-value $=0.03)$ than loans without banker directors. The coefficient estimate on Unaffiliated COMBANKER is instead $\$ 500 \mathrm{~m}(p$-value $=0.18)$. The difference is not statistically significant ( $p$-value $=0.12$ ). The affiliated banker effect in the constrained sample is significantly smaller: the $p$-value of the difference in affiliated lending in constrained and unconstrained firms ( $\$ 213 \mathrm{~m}$ versus $\$ 911 \mathrm{~m}$ ) is 0.09 . With firm fixed effects (Columns V and VI), the results are similar. Only the difference between affiliated and unaffiliated 
bankers in unconstrained firms is less pronounced. ${ }^{29}$

Overall, we consistently find significantly larger bank loans when commercial bankers are present on the board. The estimated effect is larger for affiliated than for unaffiliated deals, though the difference is statistically insignificant. However, the estimated effect of affiliated bankers is significantly stronger in unconstrained firms than in constrained firms. These findings mirror our investment-cash flow sensitivity results. Together, the results are hard to reconcile with the hypotheses that bankers on the board ease inefficient financing constraints or provide superior monitoring, i.e., curb wasteful investment when free cash flow is high, at least on average. They are, however, consistent with the hypothesis that bankers lend in the best interest of the bank.

We corroborate these results by merging the information about banker affiliation from the loan data with our earlier firm-year sample to test for the effect of affiliation in the investment-cash flow framework. We classify a commercial banker director as affiliated if her bank has lent to the firm in the past, including participation in a syndicate. ${ }^{30}$ In Columns III and IV of Table 4, we reestimate the split sample results of Columns I and II with separate dummies for affiliated and unaffiliated commercial bankers. This specification includes firm effects and the interactions of firm effects with cash flow. In the constrained subsample, the coefficients on both banker cash flow interactions (affiliated and unaffiliated) are positive, though insignificant. In the unconstrained subsample, both coefficients are negative and significant. The affiliated banker interaction (-0.378), however, is significantly larger than the unaffiliated banker interaction (-0.081). The difference is significant with a $p$-value of 0.05 . Thus, even though the direct effect of affiliation on lending is not conclusive, the reduction in cash flow sensitivity depends on a lending relationship with the director's bank.

\subsubsection{Investment opportunities, earnings, and capital structure}

To gain additional insight into the value implications of increased lending, we ex-

\footnotetext{
${ }^{29}$ Notably, the investment banker effect also becomes significant in the fixed effects regressions.

${ }^{30}$ We also designed two alternative classification schemes to check whether, instead of capturing the impact of a banker-director, the estimated effect is due to a pre-existing bank-firm relationship. First, we create a third category of "grey" commercial bankers who join a firm with a pre-existing lending relationship with their bank. Isolating them does not change the estimated impact of the remaining affiliated bankers. Second, we drop firm-years that contain banker-directors who we cannot classify due to the censoring of Dealscan before 1988. Our initial scheme classifies bankers who are already on the board in 1988 as unaffiliated until the first affiliated loan, to bias against an affiliation result. The results are, again, similar.
} 
amine whether firms that receive extra funding from banker directors have profitable investment opportunities. We also ask whether the extra lending might provide benefits to shareholders that valuation ratios fail to capture, such as an improved capital structure.

In an ideal empirical analysis, we would evaluate whether the marginal project financed with a director-banker's loan creates or destroys value. Two data limitations hamper such an analysis. First, we cannot link loans to specific projects. Second, we cannot link specific projects to their marginal returns. We are limited to considering the joint effect of lending on all ongoing projects and the resulting overall performance. As a result, even when the marginal contribution of a loan-financed project is negative, we might find a positive mean performance. In the context of external investment, i.e., acquisitions (see Section 4.1), we are able to separate these effects since we can identify the timing and return implications of distinct acquisitions.

In the context of internal investment, we partially remedy these limitations using industry performance as the hypothetical counterfactual, i.e., the returns to investment without the additional lending and resulting additional investment. For each firm-year, we subtract the median industry value from the performance measure. We use four measures: return on assets (ROA), return on equity (ROE), Tobin's Q, and Altman's z-score. We use the Fama and French 48 industry groups unless there are fewer than five sample firms in an industry. ${ }^{31}$ We consider a seven-year window around loans (year -3 to year +3 , with year 0 indicating the year of borrowing) and calculate the mean industryadjusted value of each performance measure separately for each group of borrowers in each year. ${ }^{32}$ We also evaluate the performance of firms with affiliated loans relative to borrowers with no bankers or with only unaffiliated bankers on their boards.

The left column of Fig. 2 displays the performance of unconstrained firms. ${ }^{33}$ Starting with accounting performance, we find that firms with affiliated loans perform equal to or insignificantly worse than the industry benchmark in each year prior to lending and significantly worse post-lending, in years 1 and 2 for ROA and years 1 and 3 for ROE. In contrast, firms with bank loans but unaffiliated bankers outperform their indus-

\footnotetext{
${ }^{31}$ If there are fewer than five sample firms in an industry category, the Fama-French 17 group is used. If there are fewer than five sample firms in any of these groups, the Fama-French 12 group is used.

${ }^{32} \mathrm{We}$ confirm the robustness of our results to using medians.

${ }^{33}$ Tables of the means and of all differences-in-means tests are available from the authors.
} 
tries in every year prior to lending and post-lending, significantly so in most years. The performance of firms without bankers on their boards is indistinguishable from the industry benchmark. These results suggest that the additional lending through affiliated bankers is not justified by better ongoing or subsequent earnings. Affiliated borrowers perform persistently worse than industry peers or unaffiliated borrowers.

In addition, the trend in accounting returns post-lending is worse for affiliated borrowers. The difference in industry-adjusted ROA between affiliated-banker and nobanker borrowing firms is insignificant in all years prior to the loan and in the year of the loan, ameliorating concerns about firm heterogeneity prior to lending. In the year after the loan, however, the negative difference is marginally significant $(p=0.09)$. The effect tails off in years 2 and 3 ( $p=0.11$ and $p=0.26$ ). Thus, the year after the loan marks a unique change in relative performance. ROE displays a similar trend: the magnitude of the difference is at its minimum in year $-2(0.003)$, increases to its maximum in year 0 (0.097), and remains steady at roughly 0.06 thereafter. $^{34}$

We also find a decline in performance from the year prior to the loan to the year after the loan among affiliated borrowers. Industry-adjusted ROA declines by 0.017 ( $p=$ $0.07)$ and ROE by $0.032(p=0.05)$. Over longer horizons (year -1 to year +2 or year +3 ), the slopes remain negative, though the statistical significance diminishes (only ROE over -1 to +3 is marginally significant).

Turning to the next measure, Tobin's Q, we find that the market perceives firms with affiliated loans to have the worst investment opportunities among the three groups of firms throughout the seven-year window. In each year, unaffiliated borrowers and borrowers without bankers outperform their industries, while affiliated bankers underperform. The differences between affiliated-banker and no-banker firms are statistically significant and strongest in the years leading up to the lending decisions, at the $1 \%$ or $5 \%$ level in year -3 to year 0 , suggesting worse investment opportunities prior to the loan. The difference between affiliated and unaffiliated loans is marginally significant in year 2 and has $p$-values ranging from 0.1 to 0.14 in the other three years prior to (and including) the loan year.

\footnotetext{
${ }^{34}$ In this case, the estimates are more precise: the difference between firms with affiliated bankers and no bankers is statistically significant in all years but year -2 .
} 
Finally, firms with affiliated loans have persistently lower z-scores than the industry norm and than each of the other subgroups of borrowers, though the differences are small and insignificant in most years.

The right column of Fig. 2 shows that the performance of constrained firms does not differ across types of lending for any of the four performance measures.

Thus, among financially unconstrained firms the additional bank loans to affiliated borrowers neither reflect superior investment opportunities prior to the loan nor generate higher earnings after the loan. Firms that obtain bank loans from their directors' banks are significantly worse performers and have worse investment opportunities, compared both to the industry and other borrowers. However, we must be cautious in interpreting the results, given the measurement issues outlined above.

As a final step, we ask whether affiliated lending may provide benefits to shareholders that the valuation ratios fail to capture. In particular, lending might move a firm's capital structure closer to an optimal level. Graham (2000) finds, for example, that firms tend to use debt too conservatively relative to its tax benefits. The pattern is particularly true of large, liquid, and profitable firms with low distress costs, which is precisely the type of firm in our unconstrained subsample. This interpretation would require the additional loans to have a persistent effect on leverage.

We test for significant and persistent increases in firm leverage following (affiliated) loans to unconstrained firms. We use the definitions of book and market leverage from Section 2 and also check the robustness of the results to using the following alternative definitions: the difference in assets and book equity divided by assets for book leverage and divided by assets minus book equity plus market equity for market leverage. We regress the post-borrowing change in leverage on the banker dummies and controls for the change in the ratio of plant, property, and equipment over total assets; change in Tobin's Q; change in the natural logarithm of sales; change in ROA; and the natural log of board size. We also include year and the Fama-French 17 industry dummies. ${ }^{35}$

We find that affiliated bankers lead to a significantly larger increase in book leverage (using either measure) from the end of the fiscal year prior to borrowing to the end

\footnotetext{
${ }^{35}$ The results are also robust to including credit rating dummies, as elsewhere in the paper.
} 
of the first full fiscal year after borrowing than nonbanker directors. The difference between unaffiliated and affiliated bankers, however, is not statistically significant and disappears by the end of the third year following the loan. Moreover, there are few significant estimates if we consider market rather than book leverage. Finally, the results are not robust to minor changes in variable definitions, e.g., the treatment of directors whose bank had a lending relationship with the firm prior to their appointment to the board.

In summary, there is little evidence that the larger loans provided by affiliated bankers carry through to leverage. Even the effect on book leverage appears to be shortlived and not part of a systematic strategy to raise leverage.

In light of these results and the performance results one might wonder whether the extra lending is actually in the interest of creditors. If extra lending induces firms to undertake value-destroying projects, it might also increase the likelihood of default. Fig. 2 reveals that, even post-borrowing, the mean z-score among affiliated borrowers never drops below 1.5. In unreported estimations, we confirm that affiliated lending does not increase default probability relative to unaffiliated lending or lending when banker directors are not present, as measured by changes in S\&P credit ratings or distance to default.

Overall, the findings suggest that bank executives use their directorships to increase lending, but mainly to firms with low financial constraints and credit risk, coupled with poor investment opportunities. On average, they appear more likely to facilitate overinvestment than to correct inefficient underinvestment.

\section{External investment and public debt financing}

Turning from internal to external investment decisions, we ask whether directors with financial expertise affect mergers and acquisitions, especially since major acquisitions require board approval. The type of financial experts most likely to affect acquisition decisions are investment bankers. Investment bankers are also most likely to be involved in public securities issues. Both as underwriters and advisors to acquisitions, they face incentive conflicts similar to those facing commercial lenders: they are charged both with maximizing bank profits and shareholder value.

\subsection{Acquisitions}

First, we ask whether directors with financial expertise help to prevent value- 
destroying acquisitions. By analyzing abnormal returns to merger bids, we can assess directly the impact of expertise on shareholder value. We use SDC data on completed mergers in which the acquirer obtains more than $50 \%$ of the target shares and with a deal value of more than $\$ 5 \mathrm{~m}$. Similar to previous literature (e.g., Baker and Savasoglu, 2002), we exclude leveraged buyouts, recapitalizations, self-tenders, acquisitions of subsidiaries, spin-offs, exchange offers, repurchases, minority stake purchases, privatizations, and acquisitions of remaining interests.

The summary statistics are in Panel A of Table 7. About $30 \%$ of the target firms are publicly traded, compared to less than $7 \%$ in the raw SDC data. The average target value is $\$ 214 \mathrm{~m}$, or $7 \%$ of the acquirer's total assets. In $16 \%(26 \%)$ of the acquiring companies, investment (commercial) bankers sit on the board. Panel A also shows the differences between acquiring firms with and without investment bankers on the board. (and $p$ values from $t$-tests, with clustering at the industry level). Targets acquired by firms with investment banker directors are significantly more likely to be public and are larger, both in absolute dollar terms and as a percentage of the acquirer's size. The presence of commercial bankers and executives of nonbank financial institutions do not vary significantly, but firms with investment bankers are less likely to have outside finance executives and accountants or to have finance professors on their board. In untabulated probit regressions, we also find that, controlling for an array of firm characteristics and fixed effects (Fama-French 48 industries, year, and credit rating), firms with investment bankers on the board acquire at roughly the same frequency as other firms.

As a first step towards assessing the value implications of mergers with and without investment banker directors, we analyze the announcement effects. We compute cumulative abnormal returns (CAR) over a five-day window around the announcement date as the sum of the daily differences between raw returns and the CRSP value-weighted index returns. ${ }^{36}$ The mean CAR is $-1.33 \%(p=0.04)$ in firms with investment bankers and $-0.32 \%(p=0.25)$ in firms without. The difference has a $p$-value of 0.11 . The difference in medians is identical, at 1.01 percentage points. The $1.33 \%$ decline in the investment banker subsample is three times as large as the average CAR in the overall sample.

\footnotetext{
${ }^{36}$ We use $\alpha=0$ and $\beta=1$ since the market beta is likely close to one for our sample firms and because of the short window. The assumption eliminates biases in the returns estimation due to noise in the joint estimation of alphas and betas. However, the market model results with estimated alphas and betas are similar.
} 
In Panel $\mathrm{B}$, we move to a regression framework. We relate cumulative abnormal returns to the presence of each type of finance expert on the board, controlling for board size, board independence, as well as year, industry and credit rating fixed effects. The results confirm the pattern in the means. The estimated impact of investment bankers is -1 percentage point, marginally significant at the $10 \%$ level. The result loses significance after introducing more merger-specific controls - dummies for the type of financing and whether the acquisition is diversifying - but the size of the estimated effect remains the same ( -1 percentage point). We also find that the effect is driven by private targets. For the subsample of private targets, the size of the investment banker effect doubles and becomes significant at the 5\% level. For public targets, there is no effect. These differences may reflect the more subjective valuation of private targets. The value consequences of mergers with private targets are less obvious, making it easier for management or investment bankers to direct the board and shareholders towards approval of value-destroying mergers.

We also estimate a significantly positive effect of 0.8 percentage points for nonbank finance executives in the full sample. And, financial executives and accountants have a positive effect ( 1 percentage point) in the sample of private targets. This result is consistent with a positive governance role for financial executives and accountants, who are often identified as ideal directors (Stuart, 2005).

We then examine whether the underperformance of mergers in firms with investment banker directors reverts over longer horizons. We analyze buy-and-hold returns over $+/-36$ months around each acquisition, compounded monthly over the relevant interval. In Fig. 3, we display the buy-and-hold returns from month 0 to month $x$ up to $x=36$. For months -36 to 0 , we display the buy-and-hold returns from month $-x$ to 0 , downward shifted so that the cumulative return as of month 0 is zero.

The left graph in Fig. 3 shows monthly raw returns, compounded for each merger event and then averaged in the subsamples with and without investment bankers. Acquirers without investment bankers display similar or better performance in the three years prior to the merger and their performance trend continues smoothly post-merger. In contrast, acquirers with investment bankers perform worse post-merger, both relative to their own prior performance and relative to acquirers without investment banker directors. The 
difference in abnormal returns is even more striking. In the right panel, we subtract market returns (CRSP value-weighted index) from the monthly raw returns before compounding. Firms without investment bankers again display a smooth trend of performance both prior to and post-merger. Firms with investment bankers, however, revert from positive to negative abnormal returns after the merger. We find the same results using alternative models of abnormal returns (e.g., subtracting full sample industry mean returns or industry mean returns and the firm-specific pre-event average difference between firm and industry mean returns). We also confirm in a regression framework including firm and merger characteristics that the negative announcement returns are not reversed over longer horizons.

As in any long-run event study, our results may be explained by the event or by the (mis-)specification of expected returns. This concern is ameliorated in our context since we observe the same pattern - a kink at the merger month for firms with investment bankers, but none for firms without - using several different expected return assumptions and in the raw returns, i.e., without any (potentially biased) expected return adjustment.

We conclude that investment bank directors are associated with worse investments in outside targets.

\subsection{Size and cost of public debt issues}

Mirroring our analysis of internal investment and bank financing, we turn from acquisitions to financing choices. Given investment bankers' expertise, we focus on public debt issues. ${ }^{37}$

We obtain contractual data on public debt issues from SDC. The summary statistics are in Table 8 . The sample includes 202 debt issuances underwritten by a director's investment bank, 765 issues where none of the directors' banks are involved, and 3,147 deals without investment bankers on the board. As with loans, affiliated deals tend to be larger $(\$ 176.47 \mathrm{~m})$ than unaffiliated issues $(\$ 114.33 \mathrm{~m})$ or issues of firms without banker directors $(\$ 100.76 \mathrm{~m})$, significantly so when measured as a percentage of firm value (for affiliated versus unaffiliated, $p=0.06$ ). The average cost of borrowing, measured as gross spread (underwriter fees as a percentage of the principal), is lowest for unaffiliated deals. The difference in the spread relative to affiliated issues is significant at the $1 \%$ level.

\footnotetext{
${ }^{37} \mathrm{We}$ also analyze equity issues, but, given the small sample, do not find significant results.
} 
In Table 9, we test whether the presence of financial experts on a board affects the size and pricing of debt issues, controlling for the full set of firm and board characteristics as well as for borrower and deal characteristics from the previous empirical literature. ${ }^{38}$

In Columns I and II, we document the size results. The presence of an investment banker is associated with a $\$ 20.1 \mathrm{~m}$ larger deal, marginally significant at the $10 \%$ level. The magnitude is economically significant: it is equal to $19 \%$ of the average principal in the sample. As in our analysis of bank lending, the estimates are larger for affiliated than for unaffiliated deals, but the difference lacks statistical significance $(p=0.16)$ : the coefficient estimate on Affiliated IBANKER is $\$ 64.8 \mathrm{~m}(p=0.09)$, compared with only $\$ 4.7 \mathrm{~m}$ $(p=0.72)$ for Unaffiliated IBANKER ${ }^{39}$ In unreported estimations, we also find that investment bankers are associated with more frequent outside financing. Thus, as in the commercial banker setting, the larger issues appear to generate more capital inside the firm.

In Column III, we analyze the pricing of public debt. We observe an insignificant and small negative effect of affiliated investment bankers on gross spread and a significantly negative effect of much larger magnitude for unaffiliated investment bankers. The coefficient estimate is -0.063 ( $p=0.02$, different from the affiliated coefficient at the $10 \%$ level), which corresponds roughly to $11 \%$ of the sample mean of gross spread. Thus, firms with investment bankers on the board enjoy reduced costs of public borrowing, but only when the director's bank is not involved in the deal.

Overall, the impact of investment bankers on public debt issues mirrors that of commercial bankers on loans, though the effects are estimated less precisely. Investment bankers are associated with larger issues, especially if their bank is an underwriter. They are able to lower underwriting fees - possibly due to their negotiation skills and industry networks - but do so only when the deal is not with their own bank.

\section{Financial expertise in the absence of conflicts of interest}

Our analysis shows that financial experts affect corporate decisions from which

\footnotetext{
${ }^{38}$ See, e.g., Datta, Iskandar-Datta, and Patel (1999). See the Appendix for further details on these variables.

${ }^{39}$ The result is robust to scaling debt size by total market value. The size and price results are not robust to including firm effects.
} 
their financial institutions can benefit. Financial experts without such incentives do not exert any systematic influence. As the last step in our analysis, we turn to a corporate decision for which the interests of financial institutions and shareholders do not conflict, but financial expertise is still valuable: the design of executive compensation.

The common rationale for stock-based compensation is to align CEO and shareholder interests. It is a subject of debate, however, whether the explosion of option compensation in the 1990s was the solution to or the result of such agency problems. One view is that it reflects changing CEO incentives over the last two decades (Gabaix and Landier, 2006). An alternative view is that the emergence of stock options allowed CEOs to extract additional rents since options are less transparent than cash (e.g., they did not need to be expensed in annual reports) and therefore less likely to violate the shareholders' "outrage constraint" (Bebchuk and Fried, 2003). From both perspectives, more financial literacy of directors is desirable - either to implement option compensation or to prevent abuses.

In Table 10, we test whether financial experts on corporate boards affect CEO compensation. For this analysis, we supplement the 1988-1994 Hall and Liebman data with ExecuComp data from 1995-2003. We include an indicator variable for the ExecuComp sample years to control for differences in the valuation of CEO option grants.

First, we ask whether the initiation and size of option compensation is related to the arrival of financial experts on the board. Size is calculated as the natural logarithm of one plus the Black-Scholes value. We include a standard set of controls (current and lagged stock returns, CEO age and its square, CEO tenure and its square, firm size, board size, board independence, and year fixed effects) and firm fixed effects. We find that finance professors exert a marginally significant positive effect $(p$-value $=0.06)$ on initiation (Column I) and an insignificantly positive effect $(p$-value $=0.16)$ on grant size (Column II). No other type of financial expert exerts a significant effect. In an alternative specification, using the number of financial experts of each type instead of dummies, the impact of finance professors becomes significant both for initiation $(p=0.02)$ and grant size $(p=0.06)$, while the effects of all other types of financial experts remain insignificant.

Second, we ask whether financial expertise affects pay-performance sensitivity. We relate changes in the natural logarithms of one plus total compensation (Column III) 
and one plus cash compensation (Columns IV) to current and lagged stock performance, following Hall and Liebman (1998). ${ }^{40}$ We find that finance professors are associated with lower sensitivity. For bankers and other finance experts, we do not find significant effects other than one negative coefficient for investment bankers.

Perhaps surprisingly, finance professors appear to simultaneously increase the size of option grants and to reduce or not affect pay-performance sensitivity. Since the value consequences of pay-performance sensitivity are difficult to assess, the estimated effects are consistent with (at least) two interpretations. One interpretation is that increased option grants improve incentives and our pay-performance model does not detect the improvement since it neglects the effect of stock price changes on CEO stock and option holdings. Another possibility is that finance professors facilitate additional stock option grants, and perhaps unintentionally, foster CEO rent extraction.

Overall, there is little evidence that financial expertise on the board matters at all for compensation policies. Without strong incentives (as in the case of loans for commercial bankers and in the case of security issuances for investment bankers), financial experts appear to exert little detectable influence on firm policies.

\section{Conclusion}

This paper tests whether directors with financial expertise exert significant influence on corporate decisions and, if so, whether they serve shareholders' interests. We employ a novel long-term panel data set that allows us to move beyond the crosssectional analysis prevalent in previous literature. We find that finance experts significantly affect the finance and investment policies of firms on whose board they serve. Commercial bankers reduce the sensitivity of investment to cash flow by extending large loans, particularly through the director's bank. However, firms that are financially constrained do not benefit from the additional financing. Banker directors increase financing only to firms with good credit and minimal financial constraints, but poor investment opportunities. These results suggest that banker directors act in the interest of creditors. In-

\footnotetext{
${ }^{40}$ We splice cash compensation from ExecuComp (TCC) with the sum of salary and bonus from Hall and Liebman. We splice total compensation from ExecuComp (TDC1) with the sum of salary, bonus, other compensation, restricted stock grants and the Black-Scholes value of options grants from Hall-Liebman. Ideally, we would also measure how changes in performance affect CEO wealth (including existing stock and option holdings). Unfortunately, ExecuComp does not provide data on individual option packages.
} 
vestment bankers are associated with larger debt issues and worse acquisitions. Searching for a silver lining, we test whether financial experts improve policies when their interests are not in conflict with those of shareholders. In the context of executive option grants and pay-performance sensitivity, we find little evidence to support this hypothesis.

Our findings suggest that the recent quest for increased financial expertise on boards should be implemented with caution. The impact of board members on firm policies goes beyond mere monitoring, and is affected by director interests that conflict with those of shareholders. While the overall impact of financial experts on shareholder value is difficult to assess, specific policies - like financing, investment, and compensation - do not seem to improve when financial experts join the board of directors. Firms and policy makers must trade off potential improvements in monitoring against potential losses through the advisory channel. 


\section{Appendix: Data on Loan and Debt Contracts}

\section{Loan Contract Variables (Source: The Loan Pricing Corporation's Dealscan Database)}

All-in spread

(drawn)

Maturity

Deal or Tranche

Senior

Secured

Year

Loan Style

Loan Purpose
The amount that the borrower pays the lender each year for each dollar borrowed in the case of a term loan, and for each dollar drawn off a credit line in the case of a loan commitment. The drawn all-in spread equals the coupon spread plus the annual fee. Most spreads are measured as a markup over LIBOR. In cases in which they are based on another benchmark, LPC makes adjustments to the drawn all-in spreads, by assuming the following rates: Prime $=+255 \mathrm{bps}$, Cost of funds $=0 \mathrm{bps}$, Commercial paper $=3 \mathrm{bps}$, T-bills $=-34 \mathrm{bps}$, Fed funds $=0 \mathrm{bps}$, Money market rate $=0$ bps, Banker's acceptance $=-18$ bps, CDS $=-6$ bps (Kroszner and Strahan, 2001b).

Natural logarithm of the number of days between the loan origination and the maturity.

Loan value in U.S. dollars. A deal may include several loan facilities at the same time. The most typical arrangement is a loan agreement that comprises a term loan and a revolver credit line.

Dummy variable that is equal to one if the loan is senior.

Dummy variable that is equal to one if the loan is secured. Since this variable is often missing (for about one-third of the sample), a dummy for missing cases is also included in all regressions (not shown).

Dummy variables for the calendar years in which a loan agreement is signed.

Dummy variables for "Revolver," "Limited Line," "Bridge Loan," "Demand Loan," "364-day facility," and "Other." The omitted case is "Term Loan."

Dummy variables for "Acquisition line," "CP backup," "Debt repay," "Debtor-inpossession financing," "ESOP," "LBO/MBO," "Project finance," "Real estate," "Recapitalization," "Securities purchase," "Spin-off," "Stock buyback," "Takeover," and "Working capital." The omitted case is "Corp. purposes."

Public Debt Variables (Source: SDC)

At-issue yield Yield-to-maturity in basis points as a spread over the relevant Treasury benchmark.

Gross spread Underwriter fees as a percentage of the principal issued.

Maturity The number of days between the loan origination and maturity.

Principal

Issue size in U.S. dollars.

OTC Indicates whether the issue is listed over the counter.

Indicators included in estimations but not shown in tables

CALL dummies Indicators for each of the call covenant descriptions given by SDC: "Non-call life," "Non-callable," "Non-call/refund," "Non-refundable," "Make whole call."

PUT Indicates whether the SDC gives a description of the put covenant.

SINK Indicates whether the issue involves a sinking-funds provision.

FLOAT Indicates whether the coupon rate is not fixed. 


\section{REFERENCES}

Adams, R., Ferreira, D., 2007. A theory of friendly boards. Journal of Finance 62, 217-250.

Agrawal, A., Chadha, S., 2005. Corporate governance and accounting scandals. Journal of Law and Economics 48, 371-406.

Ajinkya, B., Gift, M., 1985. Dispersion of financial analysts' earnings forecasts and the (option model) implied standard deviations of stock returns. Journal of Finance 40, 1353-1365.

Altman, E., 1968. Financial ratios, discriminant analysis, and the prediction of corporate bankruptcy. Journal of Finance 23, 589-609.

Baker, M., Savasoglu, S., 2002. Limited arbitrage in mergers and acquisitions. Journal of Financial Economics 64, 91-116.

Baker, M., Stein, J., Wurgler, J., 2003. When does the market matter? Stock prices and the investment of equity-dependent firms. Quarterly Journal of Economics 118, 969-1005.

Bebchuk, L. and Fried, J., 2003. Executive compensation as an agency problem. Journal of Economic Perspectives 17, 71-92.

Booth, J., Deli, D., 1999. On executives of financial institutions as outside directors. Journal of Corporate Finance 5, 227-250.

Boyd, J., Prescott, E., 1986. Financial intermediary-coalitions. Journal of Economic Theory $38,211-232$.

Calomiris, C., Himmelberg, C., Wachtel, P., 1995. Commercial paper, corporate finance, and the business cycle: a microeconomic perspective. Carnegie-Rochester Conf. Ser. Public Policy 42, 203-250.

Chang, X., Dasgupta, S., Hilary, G., 2006. Analyst coverage and financing decisions. Journal of Finance 61, 3009-3048.

Defond, M., Hann, R., Hu, X., 2005. Does the market value financial expertise on audit committees of boards of directors? Journal of Accounting Research 43, 153-193.

Datta, S., Iskandar-Datta, M., Patel, A., 1999. Bank monitoring and the pricing of corporate public debt. Journal of Financial Economics 51, 435-449.

Douglas, M., 2003. Bankruptcy court empowered to recharacterize debt as equity. Business Restructuring Review 2, 1-3.

Fazzari, S., Hubbard, R., Petersen, B., 1988. Financing constraints and corporate investment. Brookings Papers on Economic Activity 19, 141-195.

Fich, E., Shivdasani, A., 2006. Are busy boards effective monitors? Journal of Finance 61, 689-724.

Frank, M., Goyal, V., 2003. Testing the pecking order theory of capital structure. Journal of Financial Economics 67, 217-248. 
Gabaix, X., Landier, A., 2006. Why has CEO pay increased so much? Unpublished working paper. MIT.

Gorton, G., Winton, A., 2003. Financial intermediation. In: Constantinides, G., Harris, M., Stulz, R. (Eds.), Handbook of the Economics of Finance Volume 1A, Corporate Finance. Elsevier, North Holland.

Graham, J., 2000. How big are the tax benefits of debt? Journal of Finance 55, 1901-1941.

Güner, A. B., 2006. Loan sales and the cost of corporate borrowing. Review of Financial Studies 19, 687-716.

Hall, B., Liebman, J., 1998. Are CEOs really paid like bureaucrats? Quarterly Journal of Economics 113, 653-691.

Hellmann, T., Puri, M., 2002. Venture capital and the professionalization of start-up firms: Empirical evidence. Journal of Finance 57, 169-197.

Hermalin, B., Weisbach, M., 1988. The determinants of board composition. RAND Journal of Economics 19, 589-606.

Hermalin, B., Weisbach, M., 1998. Endogenously chosen boards of directors and their monitoring of the CEO. American Economics Review 88, 96-118.

Hermalin, B., Weisbach, M., 2003. Boards of directors as an endogenously determined institution: a survey of the economic literature. Federal Reserve Bank of New York Economic Policy Review 9, 7-26.

Holmström, B., Kaplan, S., 2003. The state of U.S. corporate governance: what's right and what's wrong? Journal of Applied Corporate Finance 15, 8-20.

Hoshi, T., Kashyap, A., Scharfstein, D., 1991. Corporate structure, liquidity, and investment: evidence from Japanese industrial groups. Quarterly Journal of Economics $106,33-60$.

Hubbard, R., 1998. Capital-market imperfections and investment. Journal of Economic Literature 36, 193-225.

Hubbard, R., Kuttner, K., Palia, D., 2002. Are there bank effects in borrowers' cost of funds? Evidence from a matched sample of borrowers and banks. Journal of Business $75,559-581$.

Jensen, M., 1986. The agency costs of free cash flow: corporate finance and takeovers. American Economic Review 76, 323-329.

Jensen, M., Meckling, W., 1976. Theory of the firm: managerial behavior, agency costs and ownership structure. Journal of Financial Economics 3, 305-360.

Jensen, M., Murphy, K., Wruck, E., 2004. Remuneration: where we've been, how we got to here, what are the problems, and how to fix them, Unpublished working paper. Harvard University.

Kaplan, S., Zingales, L., 1997. Do investment-cash flow sensitivities provide useful measures of financing constraints? Quarterly Journal of Economics 112, 169-215. 
Kashyap, A., Lamont, O., Stein, J., 1994. Credit conditions and the cyclical behavior of inventories. Quarterly Journal of Economics 109, 565-592.

Kortum, S., Lerner, J., 2000. Assessing the contribution of venture capital to innovation. RAND Journal of Economics 31, 674-692.

Kracaw, W., Zenner, M., 1998. Bankers in the board room: good news or bad news? Unpublished working paper. Pennsylvania State University.

Kroszner, R., Strahan, P., 2001a. Bankers on boards: monitoring, conflicts of interest, and lender liability. Journal of Financial Economics 62, 415-452.

Kroszner, R., Strahan, P., 2001b. Throwing good money after bad, John M. Olin Law and Economics Working Paper. University of Chicago.

Lamont, O., Polk, C., Saá-Requejo, J., 2001. Financial constraints and stock returns. Review of Financial Studies 14, 529-554.

Loughran, T., Ritter, J., 2004. Why has IPO underpricing changed over time? Financial Management 33, 5-37.

MacKie-Mason, J., 1990. Do taxes affect corporate financing decisions? Journal of Finance 45, 1471-1493.

Malmendier, U., Shanthikumar, D., 2007. Do security analysts speak in two tongues? National Bureau of Economic Research Working Paper No 13570..

Malmendier, U., Tate, G., 2005. CEO overconfidence and corporate investment. Journal of Finance 60, 2661-2700.

Morck, R., Nakamura, M., 1999. Banks and corporate control in Japan. Journal of Finance 54, 319-339.

Moyen, N., 2004. Investment-cash flow sensitivities: constrained versus unconstrained firms. Journal of Finance 59, 2061-2092.

Myers, S., Majluf, N., 1984. Corporate financing and investment decisions when firms have information that investors do not have. Journal of Financial Economics 50, 1421-1460.

Park, S., 1994. Explanations for the increased riskiness of banks in the 1980s. Federal Reserve Bank of St. Louis Review 76, 3-24.

Perry, T., Peyer, U., 2005. Board seat accumulation by executives: a shareholder's perspective. Journal of Finance 60, 2083-2123.

Pfeffer, J., 1992. Size and composition of boards of directors: the organization and its environment. Administrative Science Quarterly 17, 218-228.

Ramirez, C., 1995. Did J.P. Morgan's men add liquidity? Corporate investment, cash flow, and financial structure at the turn of the twentieth century. Journal of Finance 50, 661-678.

Reuter, J., 2006. Are IPO allocations for sale? Evidence from mutual funds. Journal of Fi- 
nance $61,2289-2324$.

Sprayregen, J., Friedland, J., Mayer, J., 2003. Recharacterization from debt to equity: lenders beware. American Bankruptcy Institute Journal 22, 30-31.

Stearns, L., Mizruchi, M., 1993. Board composition and corporate financing: the impact of financial institution representation on borrowing. Academy of Management Journal $36,603-618$.

Stuart, A., 2005. Can you spot the finance expert? CFO Magazine 21, 62-72.

Tenorio, V., 2003. The messy reality of SOX on private equity. The Deal, June Issue.

Yermack, D., 1995. Do corporations award CEO stock options effectively? Journal of Financial Economics 39, 237-269. 
Table 1

Summary Statistics

The sample period is 1988-2001. Panel A provides summary statistics for director-years. All variables other than Age, Tenure, and Number of Other Directorships are dummy variables indicating the director's career. Panels B and C describe firm-years. Firm characteristics are from Compustat Annual (item numbers in parentheses): Assets are total assets (6), Capital is property, plant, and equipment (8), Investment is capital expenditures (128), and Cash Flow is earnings before extraordinary items (18) plus depreciation (14). Tobin's Q is the market value of assets over total assets (6), where market value is total assets plus market equity $\left(25^{*} 199\right)$ minus book equity (6-181-10+35+79). Return on Assets (ROA) is income $(18+15+50+51)$ divided by the average of current and lagged total assets. Return on Equity (ROE) is net income (172) scaled by the average of current and lagged book equity. Altman's z-score is defined as 3.3 times the difference in operating income before depreciation (13) and depreciation and amortization (14) plus sales (12) plus 1.4 times retained earnings (36) plus 1.2 times working capital (121), divided by total assets (6). Book Leverage is interest bearing debt (9+34) divided by operating assets (9+34+216). Market Leverage is interest bearing debt divided by the market value of assets. Board Size is the number of directors. Board Independence is the ratio of outside directors over board size. COMBANKER, IBANKER, (Outside) Financial Executives \& Accountants, Executives of Non-bank Financial Companies, and Finance Professors in Panel B are dummy variables indicating if at least one director has the corresponding career. In Panel C, industry dummies are based on the Fama-French 17 categories.

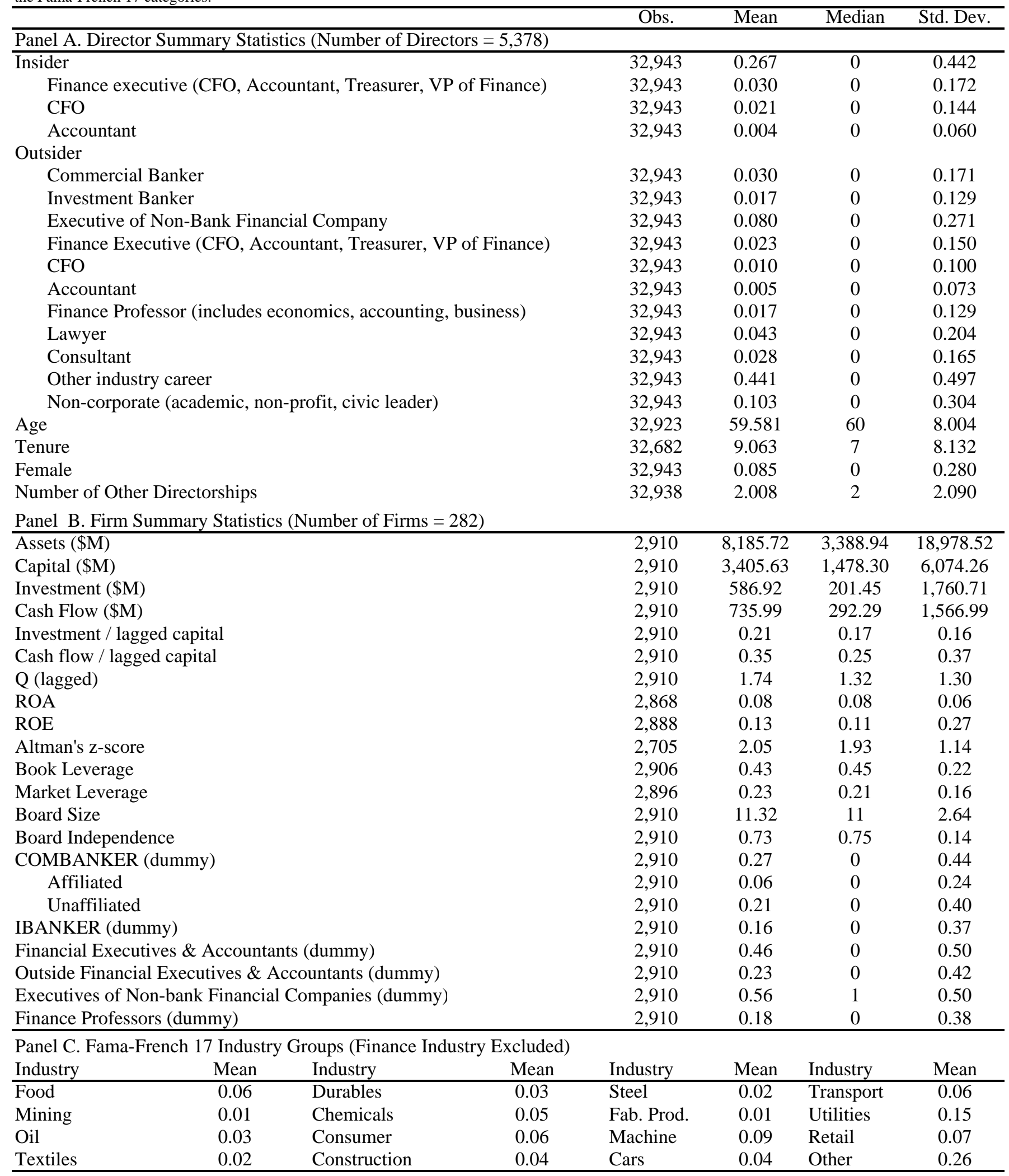


Table 2

Sensitivity of investment to cash flow: baseline regressions

OLS regressions with Investment as the dependent variable, defined as capital expenditures normalized by lagged capital. Cash Flow is earnings before extraordinary items plus depreciation, normalized by lagged capital. Q is the lagged ratio of market value of assets to book value of assets. Firm Size is the natural logarithm of lagged book assets. Board Size is the natural logarithm of the number of directors. Board Independence is the ratio of the number of outside directors to board size. COMBANKER is an indicator variable for the presence of a commercial banker on the board; IBANKER indicates an investment banker. Likewise, Executives of Non-bank Financial Companies, Financial Executives \& Accountants, and Finance Professors are dummy variables indicating the presence of such a director on the board. All regressions include year fixed effects and their interactions with Cash Flow. All regressions also include S\&P credit rating fixed effects (defined using the S\&P long-term debt rating) and their interactions with Cash Flow. Industry indicators are coded according to the FamaFrench 48 industry groups. All standard errors are clustered by firm.

\begin{tabular}{|c|c|c|c|c|}
\hline & $(\mathrm{I})$ & (II) & (III) & $(\mathrm{IV})$ \\
\hline \multirow[t]{2}{*}{ Cash Flow } & 0.461 & 0.389 & 0.382 & 0.608 \\
\hline & {$[2.13]^{* *}$} & {$[1.70]^{*}$} & {$[1.43]$} & {$[1.85]^{*}$} \\
\hline \multirow[t]{2}{*}{$($ COMBANKER)*(Cash Flow) } & & -0.116 & -0.085 & -0.066 \\
\hline & & {$[3.66]^{* * *}$} & {$[2.47]^{* *}$} & {$[1.66]^{*}$} \\
\hline \multirow[t]{2}{*}{ (IBANKER)*(Cash Flow) } & & -0.03 & -0.086 & 0.002 \\
\hline & & {$[0.69]$} & {$[1.54]$} & {$[0.04]$} \\
\hline \multirow[t]{2}{*}{$($ Executives of Non-bank Financial Cos)*(Cash Flow) } & & -0.012 & -0.066 & -0.025 \\
\hline & & {$[0.40]$} & {$[1.43]$} & {$[0.93]$} \\
\hline \multirow[t]{2}{*}{ (Financial Executives \& Accountants)*(Cash Flow) } & & 0.007 & 0.034 & 0.012 \\
\hline & & {$[0.22]$} & [1.19] & {$[0.40]$} \\
\hline \multirow[t]{2}{*}{ (Finance Professors)*(Cash Flow) } & & -0.001 & -0.068 & -0.075 \\
\hline & & {$[0.03]$} & {$[1.23]$} & {$[1.55]$} \\
\hline \multirow[t]{2}{*}{ COMBANKER } & & 0.017 & 0.035 & 0.034 \\
\hline & & {$[1.61]$} & {$[2.82]^{* * *}$} & {$[2.62]^{* * *}$} \\
\hline \multirow[t]{2}{*}{ IBANKER } & & 0.026 & 0.021 & -0.011 \\
\hline & & [1.49] & {$[1.13]$} & {$[0.54]$} \\
\hline \multirow[t]{2}{*}{ Executives of Non-bank Financial Companies } & & 0.001 & 0.020 & 0.011 \\
\hline & & {$[0.17]$} & [1.49] & [1.13] \\
\hline \multirow[t]{2}{*}{ Financial Executives \& Accountants } & & 0.008 & -0.001 & 0.010 \\
\hline & & {$[0.89]$} & {$[0.05]$} & {$[0.94]$} \\
\hline \multirow[t]{2}{*}{ Finance Professors } & & 0.007 & 0.016 & 0.009 \\
\hline & & {$[0.44]$} & {$[0.75]$} & {$[0.46]$} \\
\hline \multirow[t]{2}{*}{ Q } & 0.024 & 0.029 & 0.032 & 0.027 \\
\hline & {$[2.18]^{* *}$} & {$[2.48]^{* *}$} & {$[2.95]^{* * *}$} & {$[2.66]^{* * *}$} \\
\hline \multirow[t]{2}{*}{$(\mathrm{Q}) *($ Cash Flow $)$} & 0.011 & 0.002 & -0.001 & -0.007 \\
\hline & {$[1.24]$} & {$[0.23]$} & {$[0.10]$} & {$[0.70]$} \\
\hline \multirow[t]{2}{*}{ Firm Size } & 0.003 & 0.005 & -0.027 & 0.008 \\
\hline & {$[0.55]$} & {$[0.80]$} & {$[2.16]^{* *}$} & {$[0.58]$} \\
\hline \multirow[t]{2}{*}{$($ Firm Size $) *($ Cash Flow $)$} & -0.017 & -0.020 & -0.075 & -0.130 \\
\hline & {$[0.68]$} & {$[0.85]$} & {$[2.87]^{* * *}$} & {$[3.98]^{* * *}$} \\
\hline \multirow[t]{2}{*}{ Board Size } & 0.034 & 0.021 & -0.039 & -0.041 \\
\hline & {$[1.58]$} & {$[0.98]$} & {$[0.95]$} & {$[1.42]$} \\
\hline \multirow[t]{2}{*}{$(\text { Board Size })^{*}($ Cash Flow $)$} & -0.065 & -0.008 & 0.087 & 0.054 \\
\hline & {$[0.73]$} & {$[0.10]$} & {$[0.73]$} & {$[0.63]$} \\
\hline \multirow[t]{2}{*}{ Board Independence } & -0.093 & -0.096 & -0.115 & -0.034 \\
\hline & {$[1.84]^{*}$} & {$[2.02]^{* *}$} & {$[1.88]^{*}$} & {$[0.61]$} \\
\hline \multirow[t]{2}{*}{ (Board Independence)*(Cash Flow) } & 0.141 & 0.206 & 0.524 & 0.229 \\
\hline & {$[0.92]$} & {$[1.37]$} & {$[2.76]^{* * *}$} & {$[1.67]^{*}$} \\
\hline \multirow{2}{*}{$\begin{array}{l}\text { Industry Fixed Effects } \\
\text { (Industry Fixed Effects)*(Cash Flow) }\end{array}$} & yes & yes & no & no \\
\hline & yes & yes & yes & no \\
\hline \multirow{2}{*}{$\begin{array}{l}\text { Firm Fixed Effects } \\
\text { (Firm Fixed Effects)*(Cash Flow) }\end{array}$} & no & no & yes & yes \\
\hline & no & no & no & yes \\
\hline Observations & 2,910 & 2,910 & 2,910 & 2,910 \\
\hline $\mathrm{R}^{2}$ & 0.48 & 0.49 & 0.69 & 0.80 \\
\hline
\end{tabular}

Robust $t$-statistics in brackets. * significant at $10 \% ; * *$ significant at $5 \% ; * * *$ significant at $1 \%$. 


\section{Board Size}

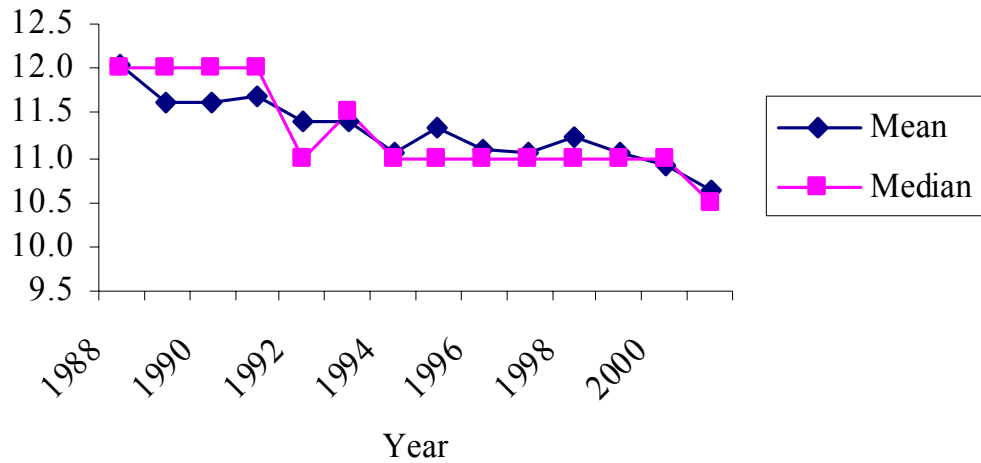

Fig 1. Board size over the sample period. The figure shows the annual mean and median board size (number of directors on the board). 
Table 3

Sensitivity of investment to cash flow: instrumental variable estimation

Investment is capital expenditures normalized by lagged capital. Cash Flow is earnings before extraordinary items plus depreciation, normalized by lagged capital. Q is the (lagged) ratio of market value of assets to book value of assets. Firm Size is the natural logarithm of lagged book assets. Board Size is the natural logarithm of the number of directors on the board. Board Independence is the ratio of the number of outside directors to board size. Board Tenure is the mean tenure of directors on the board. \#COMBANKER is the natural logarithm of one plus the number of commercial bankers on the board. CRISIS is the natural logarithm of one plus the number of directors who joined the board between 1976 and 1985. Column I shows the baseline OLS regresssion; Columns II and III the first-stage OLS regressions, using CRISIS and its interaction with Cash Flow to instrument for Commercial Bankers and its interaction with Cash Flow; the second stage is in Column IV. All regressions include year fixed effects, industry fixed effects, and their interactions with Cash Flow. All regressions also include S\&P credit rating fixed effects (using the S\&P long-term debt rating categories) and their interactions with Cash Flow. Industry indicators are coded according to the Fama-French 48 industry groups. All standard errors are clustered by firm.

\begin{tabular}{|c|c|c|c|c|}
\hline \multirow[b]{3}{*}{ Dependent variable } & \multirow{3}{*}{$\begin{array}{c}\text { (I) } \\
\text { Baseline } \\
\text { Investment }\end{array}$} & (II) & (III) & \multirow{3}{*}{$\begin{array}{c}\text { (IV) } \\
\text { 2SLS } \\
\text { Investment }\end{array}$} \\
\hline & & \multicolumn{2}{|c|}{ First Stage } & \\
\hline & & COMBANKER & $(\mathrm{COMBANKER}) *(\mathrm{CF})$ & \\
\hline \multirow[t]{2}{*}{ Cash Flow } & 0.480 & 0.355 & -0.327 & 0.256 \\
\hline & {$[2.27]^{* *}$} & {$[0.95]$} & {$[1.35]$} & {$[0.94]$} \\
\hline \multirow[t]{2}{*}{ (\#COMBANKER)*(Cash Flow) } & -0.163 & & & -0.820 \\
\hline & {$[4.09]^{* * *}$} & & & {$[1.91]^{*}$} \\
\hline \multirow[t]{2}{*}{ \#COMBANKER } & 0.023 & & & 0.202 \\
\hline & {$[1.86]^{*}$} & & & [1.09] \\
\hline \multirow[t]{2}{*}{ (CRISIS)*(Cash Flow) } & & 0.193 & 0.149 & \\
\hline & & {$[3.03] * * *$} & {$[3.97] * * *$} & \\
\hline \multirow[t]{2}{*}{ CRISIS } & & -0.095 & -0.040 & \\
\hline & & {$[2.03]^{* *}$} & {$[3.93] * * *$} & \\
\hline \multirow[t]{2}{*}{ Q } & 0.028 & 0.025 & 0.030 & 0.043 \\
\hline & {$[2.52]^{* *}$} & [1.29] & {$[2.40] * *$} & {$[2.50]^{* *}$} \\
\hline \multirow[t]{2}{*}{ (Q)*(Cash Flow) } & 0.001 & -0.040 & -0.056 & -0.028 \\
\hline & {$[0.14]$} & {$[2.64]^{* * *}$} & {$[2.70]^{* * *}$} & [1.08] \\
\hline \multirow[t]{2}{*}{ Firm Size } & 0.004 & 0.002 & 0.012 & 0.011 \\
\hline & {$[0.65]$} & {$[0.06]$} & {$[1.36]$} & {$[1.04]$} \\
\hline \multirow[t]{2}{*}{ (Firm Size)*(Cash Flow) } & -0.018 & -0.003 & -0.030 & -0.033 \\
\hline & {$[0.79]$} & {$[0.06]$} & {$[0.83]$} & [1.09] \\
\hline \multirow[t]{2}{*}{ Board Size } & 0.031 & 0.378 & 0.001 & -0.031 \\
\hline & [1.59] & {$[3.68] * * *$} & {$[0.02]$} & {$[0.45]$} \\
\hline \multirow[t]{2}{*}{ (Board Size)*(Cash Flow) } & -0.028 & -0.127 & 0.282 & 0.182 \\
\hline & {$[0.38]$} & {$[0.88]$} & {$[2.33]^{* *}$} & {$[1.20]$} \\
\hline \multirow[t]{2}{*}{ Board Independence } & -0.095 & 0.304 & 0.006 & -0.153 \\
\hline & {$[1.97]^{* *}$} & {$[2.11]^{* *}$} & {$[0.12]$} & {$[1.97]^{*}$} \\
\hline \multirow[t]{2}{*}{ (Board Independence)*(Cash Flow) } & 0.158 & -0.089 & 0.253 & 0.361 \\
\hline & {$[1.10]$} & {$[0.38]$} & {$[1.36]$} & [1.97]* \\
\hline \multirow[t]{2}{*}{ Board Tenure } & 0.001 & 0.001 & 0.001 & 0.001 \\
\hline & {$[1.86]^{*}$} & {$[2.09]^{* *}$} & {$[1.46]$} & {$[1.83]^{*}$} \\
\hline \multirow[t]{2}{*}{ (Board Tenure)*(Cash Flow) } & -0.004 & -0.005 & -0.003 & -0.004 \\
\hline & {$[1.90]^{*}$} & {$[2.21]^{* *}$} & {$[1.53]$} & {$[1.88]^{*}$} \\
\hline Observations & 2,907 & 2,907 & 2,907 & 2,907 \\
\hline $\mathrm{R}^{2}$ & 0.49 & 0.23 & 0.41 & 0.36 \\
\hline
\end{tabular}

Robust $t$-statistics in brackets. ${ }^{*}$ significant at $10 \% ;{ }^{* *}$ significant at $5 \% ;{ }^{* * *}$ significant at $1 \%$. 
Table 4

Sensitivity of investment to cash flow: split-sample results

OLS regressions with Investment as dependent variable, defined as capital expenditures normalized by lagged capital. Constrained (unconstrained) firms are those with lagged Kaplan-Zingales index values above (below) the sample median. Cash Flow is earnings before extraordinary items plus depreciation, normalized by lagged capital. Q is the (lagged) ratio of market value of assets to book value of assets. Firm Size is the natural logarithm of lagged book assets. Board Size is the natural logarithm of the number of directors on the board. Board Independence is the ratio of the number of outside directors to board size. COMBANKER is an indicator variable for the presence of a commercial banker on the board; IBANKER indicates an investment banker. Likewise, Executives of Non-bank Financial Companies, Financial Executives \& Accountants, and Finance Professors indicate the presence of such a director on the board. Affiliated COMBANKER indicates the presence of a commercial banker whose bank has a prior lending relationship with the firm. Unaffiliated COMBANKER indicates that commercial banker directors are present, but none have lending relationships. All regressions include firm and year fixed effects and their interactions with Cash Flow. All regressions also include S\&P credit rating fixed effects (using the S\&P long-term debt rating categories), and their interactions with Cash Flow. All standard errors are clustered by firm.

\begin{tabular}{|c|c|c|c|c|}
\hline & $\begin{array}{c}\text { (I) } \\
\text { Constrained }\end{array}$ & $\begin{array}{c}\text { (II) } \\
\text { Unconstrained }\end{array}$ & $\begin{array}{c}\text { (III) } \\
\text { Constrained }\end{array}$ & $\begin{array}{c}\text { (IV) } \\
\text { Unconstrained }\end{array}$ \\
\hline \multirow[t]{2}{*}{ Cash Flow } & 0.675 & 0.811 & 0.414 & 0.772 \\
\hline & {$[0.53]$} & {$[2.05] * *$} & {$[0.30]$} & {$[1.94]^{*}$} \\
\hline \multirow[t]{2}{*}{$($ COMBANKER $) *($ Cash Flow $)$} & 0.150 & -0.090 & & \\
\hline & {$[1.30]$} & {$[2.24]^{* *}$} & & \\
\hline \multirow[t]{2}{*}{ (Affiliated COMBANKER)*(Cash Flow) } & & & 0.200 & -0.378 \\
\hline & & & {$[1.30]$} & {$[2.54]^{* *}$} \\
\hline \multirow[t]{2}{*}{ (Unaffiliated COMBANKER)*(Cash Flow) } & & & 0.137 & -0.081 \\
\hline & & & {$[1.08]$} & {$[1.94]^{*}$} \\
\hline \multirow[t]{2}{*}{ (IBANKER)*(Cash Flow) } & 0.058 & 0.016 & 0.058 & 0.022 \\
\hline & {$[0.35]$} & {$[0.24]$} & {$[0.35]$} & {$[0.33]$} \\
\hline \multirow[t]{2}{*}{ (Execs of Non-bank Fin Cos)*(Cash Flow) } & 0.050 & -0.011 & 0.049 & -0.011 \\
\hline & {$[0.61]$} & {$[0.34]$} & {$[0.59]$} & {$[0.33]$} \\
\hline \multirow[t]{2}{*}{ (Fin Execs \& Accountants)*(Cash Flow) } & 0.001 & 0.03 & -0.002 & 0.029 \\
\hline & {$[0.01]$} & {$[0.71]$} & {$[0.02]$} & {$[0.67]$} \\
\hline \multirow[t]{2}{*}{ (Finance Professors)*(Cash Flow) } & 0.231 & -0.114 & 0.229 & -0.119 \\
\hline & [1.37] & {$[1.81]^{*}$} & [1.35] & [1.91]* \\
\hline \multirow[t]{2}{*}{ COMBANKER } & -0.016 & 0.055 & & \\
\hline & {$[0.80]$} & {$[2.36]^{* *}$} & & \\
\hline \multirow[t]{2}{*}{ Affiliated COMBANKER } & & & -0.027 & 0.139 \\
\hline & & & [1.14] & {$[3.23]^{* * *}$} \\
\hline \multirow{2}{*}{ Unaffiliated COMBANKER } & & & -0.013 & 0.055 \\
\hline & & & {$[0.63]$} & {$[2.22] * *$} \\
\hline \multirow[t]{2}{*}{ IBANKER } & -0.005 & -0.003 & -0.005 & -0.008 \\
\hline & {$[0.18]$} & {$[0.09]$} & {$[0.19]$} & {$[0.26]$} \\
\hline \multirow[t]{2}{*}{ Executives of Non-bank Financial Companies } & -0.004 & 0.006 & -0.004 & 0.006 \\
\hline & {$[0.27]$} & {$[0.28]$} & {$[0.26]$} & {$[0.29]$} \\
\hline \multirow[t]{2}{*}{ Financial Executives \& Accountants } & 0.01 & -0.007 & 0.011 & -0.009 \\
\hline & {$[0.56]$} & [0.33] & {$[0.58]$} & {$[0.43]$} \\
\hline \multirow[t]{2}{*}{ Finance Professors } & -0.049 & 0.046 & -0.049 & 0.049 \\
\hline & {$[1.93]^{*}$} & [1.29] & {$[1.90]^{*}$} & {$[1.35]$} \\
\hline \multirow[t]{2}{*}{ Q } & 0.060 & 0.008 & 0.060 & 0.009 \\
\hline & {$[2.33]^{* *}$} & {$[0.56]$} & {$[2.31] * *$} & {$[0.64]$} \\
\hline \multirow[t]{2}{*}{$(\mathrm{Q}) *($ Cash Flow $)$} & -0.034 & -0.001 & -0.034 & -0.001 \\
\hline & {$[0.88]$} & {$[0.04]$} & {$[0.87]$} & {$[0.09]$} \\
\hline \multirow[t]{2}{*}{ Firm Size } & 0.015 & 0.021 & 0.015 & 0.020 \\
\hline & {$[0.49]$} & {$[0.90]$} & {$[0.48]$} & {$[0.86]$} \\
\hline \multirow[t]{2}{*}{ 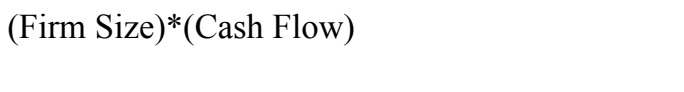 } & -0.228 & -0.114 & -0.227 & -0.112 \\
\hline & {$[1.93]^{*}$} & {$[3.36]^{* * *}$} & {$[1.92]^{*}$} & {$[3.21]^{* * *}$} \\
\hline \multirow[t]{2}{*}{ Board Size } & 0.078 & -0.034 & 0.080 & -0.027 \\
\hline & {$[1.26]$} & {$[0.48]$} & [1.28] & {$[0.41]$} \\
\hline \multirow[t]{2}{*}{ (Board Size)*(Cash Flow) } & -0.475 & 0.002 & -0.483 & 0.007 \\
\hline & {$[1.29]$} & {$[0.02]$} & {$[1.30]$} & {$[0.06]$} \\
\hline \multirow[t]{2}{*}{ Board Independence } & -0.087 & -0.082 & -0.087 & -0.074 \\
\hline & {$[0.93]$} & {$[0.79]$} & {$[0.93]$} & {$[0.73]$} \\
\hline (Board Independence)*(Cash Flow) & 0.723 & 0.075 & 0.726 & 0.065 \\
\hline & {$[1.95]^{*}$} & {$[0.43]$} & {$[1.93]^{*}$} & {$[0.38]$} \\
\hline Observations & 1,350 & 1,364 & 1,350 & 1,364 \\
\hline $\mathrm{R}^{2}$ & 0.89 & 0.84 & 0.89 & 0.84 \\
\hline
\end{tabular}

Robust $t$-statistics in brackets. * significant at $10 \% ; * *$ significant at $5 \% ; * * *$ significant at $1 \%$. 
Table 5

Summary statistics: bank loans

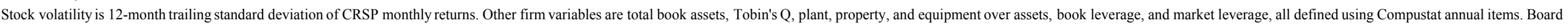

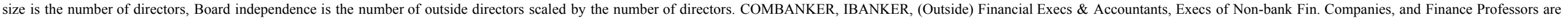

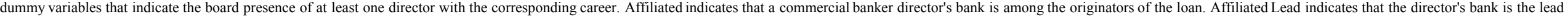

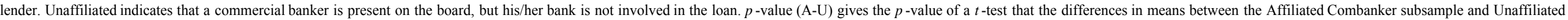

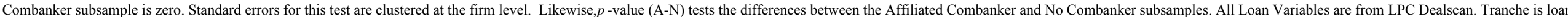

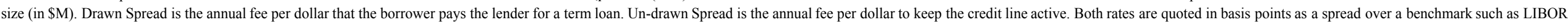

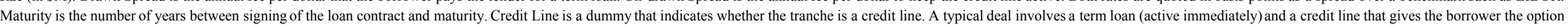

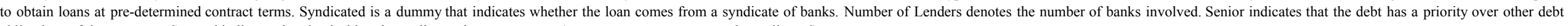
obligations of the company. Secured indicates that the deal involves a lien on borrower assets (e.g., assets, guarantees, or other collateral).

\begin{tabular}{|c|c|c|c|c|c|c|c|c|c|c|c|c|c|c|}
\hline & \multicolumn{3}{|c|}{ Full Sample } & \multicolumn{3}{|c|}{ Affiliated Commercial Banker } & \multicolumn{3}{|c|}{ Unaffiliated Commercial Banker } & \multirow{2}{*}{$\begin{array}{l}p \text {-value } \\
(\mathrm{A}-\mathrm{U})\end{array}$} & \multicolumn{3}{|c|}{ No Commercial Banker } & \multirow{2}{*}{$\begin{array}{r}p \text {-value } \\
(\mathrm{A}-\mathrm{N})\end{array}$} \\
\hline & Obs & Mean & Std Dev & Obs & Mean & Std Dev & Obs & Mean & Std Dev & & Obs & Mean & Std Dev & \\
\hline \multicolumn{15}{|l|}{ Firm Variables } \\
\hline Assets (\$M) & 1,288 & $8,724.82$ & $17,515.22$ & 89 & $14,602.66$ & $32,802.22$ & 223 & $10,490.25$ & $22,940.14$ & 0.24 & 976 & $7,785.46$ & $13,537.57$ & 0.14 \\
\hline Q & 1,288 & 1.61 & 1.15 & 89 & 1.46 & 0.59 & 223 & 1.49 & 1.13 & 0.85 & 976 & 1.65 & 1.19 & 0.15 \\
\hline PPE over Assets & 1,288 & 0.42 & 0.22 & 89 & 0.54 & 0.23 & 223 & 0.52 & 0.24 & 0.77 & 976 & 0.39 & 0.20 & 0.00 \\
\hline Stock Volatility & 1,288 & 0.08 & 0.04 & 89 & 0.07 & 0.03 & 223 & 0.07 & 0.03 & 0.75 & 976 & 0.09 & 0.04 & 0.03 \\
\hline Book Leverage & 1,288 & 0.49 & 0.19 & 89 & 0.47 & 0.20 & 223 & 0.51 & 0.19 & 0.29 & 976 & 0.49 & 0.19 & 0.68 \\
\hline Board Size & 1,288 & 11.20 & 2.57 & 89 & 12.19 & 2.47 & 223 & 11.52 & 2.34 & 0.19 & 976 & 11.04 & 2.61 & 0.03 \\
\hline Board Independence & 1,288 & 0.73 & 0.14 & 89 & 0.77 & 0.09 & 223 & 0.76 & 0.12 & 0.38 & 976 & 0.72 & 0.14 & 0.01 \\
\hline COMBANKER & 1,288 & 0.24 & 0.43 & 89 & 1 & 0 & 223 & 1 & 0 & n.a. & 976 & 0 & 0 & n.a. \\
\hline Affiliated & 1,288 & 0.07 & 0.25 & 89 & 1 & 0 & 223 & 0 & 0 & n.a. & 976 & 0 & 0 & n.a. \\
\hline Unaffiliated & 1,288 & 0.17 & 0.38 & 89 & 0 & 0 & 223 & 1 & 0 & n.a. & 976 & 0 & 0 & n.a. \\
\hline Affiliated Lead & 1,288 & 0.04 & 0.19 & 89 & 0.52 & 0.50 & 223 & 0 & 0 & n.a. & 976 & 0 & 0 & n.a. \\
\hline IBANKER & 1,288 & 0.21 & 0.41 & 89 & 0.20 & 0.40 & 223 & 0.11 & 0.32 & 0.17 & 976 & 0.23 & 0.42 & 0.71 \\
\hline Accountants & 1,288 & 0.12 & 0.33 & 89 & 0.01 & 0.11 & 223 & 0.07 & 0.25 & 0.09 & 976 & 0.14 & 0.35 & 0.00 \\
\hline CFOs & 1,288 & 0.32 & 0.47 & 89 & 0.31 & 0.47 & 223 & 0.29 & 0.45 & 0.73 & 976 & 0.33 & 0.47 & 0.82 \\
\hline Outside Fin Execs \& Accountants & 1,288 & 0.23 & 0.42 & 89 & 0.22 & 0.42 & 223 & 0.21 & 0.41 & 0.80 & 976 & 0.24 & 0.43 & 0.82 \\
\hline Outside Accountants & 1,288 & 0.06 & 0.24 & 89 & 0 & 0 & 223 & 0.05 & 0.22 & 0.14 & 976 & 0.07 & 0.26 & 0.00 \\
\hline Outside CFOs & 1,288 & 0.12 & 0.33 & 89 & 0.16 & 0.37 & 223 & 0.10 & 0.30 & 0.34 & 976 & 0.13 & 0.33 & 0.59 \\
\hline Execs of Non-bank Fin Cos & 1,288 & 0.56 & 0.50 & 89 & 0.49 & 0.50 & 223 & 0.55 & 0.50 & 0.52 & 976 & 0.57 & 0.49 & 0.40 \\
\hline Finance Professors & 1,288 & 0.14 & 0.34 & 89 & 0.13 & 0.34 & 223 & 0.12 & 0.33 & 0.87 & 976 & 0.14 & 0.35 & 0.94 \\
\hline \multicolumn{15}{|l|}{ Loan Variables } \\
\hline Tranche (\$M) & 1,288 & 644.24 & $1,254.56$ & 89 & $1,408.93$ & $2,993.20$ & 223 & 649.42 & $1,588.62$ & 0.03 & 976 & 573.33 & 797.43 & 0.03 \\
\hline Tranche / Market Value of Firm & 1,288 & 0.08 & 0.10 & 89 & 0.11 & 0.12 & 223 & 0.07 & 0.10 & 0.08 & 976 & 0.08 & 0.10 & 0.20 \\
\hline Drawn Spread (basis points) & 1,024 & 81.94 & 85.42 & 78 & 57.79 & 57.56 & 155 & 80.38 & 88.59 & 0.15 & 791 & 84.62 & 86.77 & 0.05 \\
\hline Un-drawn Spread (basis points) & 817 & 18.24 & 14.26 & 69 & 15.30 & 12.12 & 126 & 18.72 & 14.70 & 0.15 & 622 & 18.47 & 14.37 & 0.15 \\
\hline Maturity & 1,108 & 3.54 & 2.58 & 85 & 3.68 & 2.28 & 185 & 3.77 & 3.58 & 0.86 & 838 & 3.47 & 2.34 & 0.47 \\
\hline Credit Line & 1,288 & 0.60 & 0.49 & 89 & 0.63 & 0.49 & 223 & 0.57 & 0.50 & 0.40 & 976 & 0.61 & 0.49 & 0.69 \\
\hline Syndicated & 1,288 & 0.85 & 0.36 & 89 & 0.94 & 0.23 & 223 & 0.81 & 0.40 & 0.02 & 976 & 0.85 & 0.36 & 0.02 \\
\hline Number of Lenders & 1,288 & 12.33 & 12.84 & 89 & 19.35 & 17.10 & 223 & 8.46 & 9.22 & 0.00 & 976 & 12.58 & 12.80 & 0.03 \\
\hline
\end{tabular}


Table 6

Loan size regressions

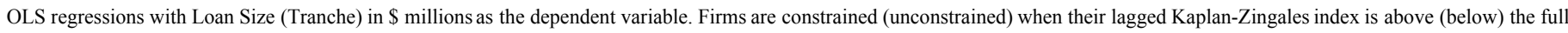

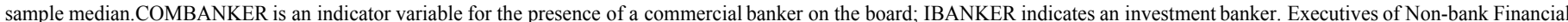

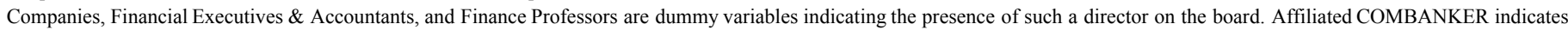

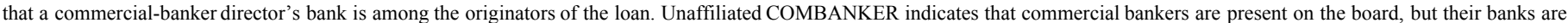

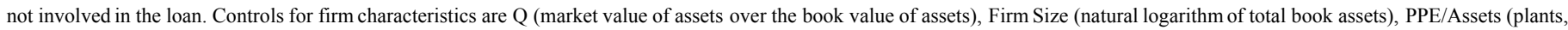

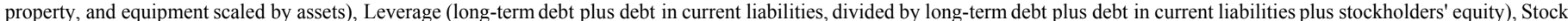

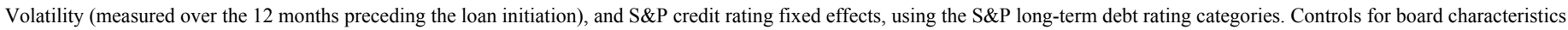

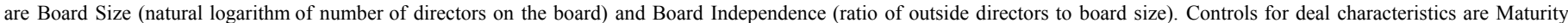

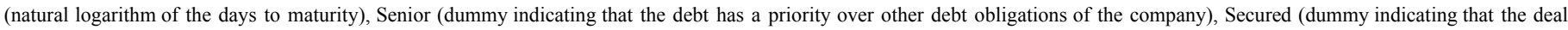

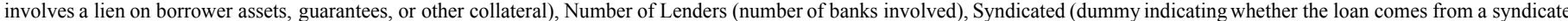

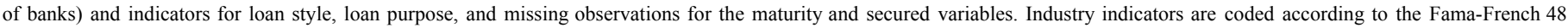
industry groups. All standard errors are clustered by firm.

$\begin{array}{llllll}\text { (I) } & \text { (II) } & \text { (III) } & \text { (IV) } & \text { (V) } & \text { (VI) }\end{array}$

COMBANKER

Full Sample Full Sample Constrained Unconstrained Constrained Unconstrained

\begin{tabular}{|c|c|c|c|c|c|c|}
\hline COMBANKER & $\begin{array}{c}346.729 \\
{[1.86]^{*}}\end{array}$ & & & & & \\
\hline Affiliated COMBANKER & & 458.393 & 213.364 & 910.576 & 47.226 & $1,464.07$ \\
\hline & & {$[2.18]^{* *}$} & {$[1.86]^{*}$} & {$[2.25]^{* *}$} & {$[0.38]$} & {$[2.14]^{* *}$} \\
\hline Unaffiliated COMBANKER & & 295.692 & 121.316 & 500.442 & -17.887 & $1,341.58$ \\
\hline & & {$[1.57]$} & {$[1.78]^{*}$} & {$[1.35]$} & {$[0.20]$} & {$[1.29]$} \\
\hline IBANKER & 203.157 & 200.727 & 73.851 & 365.428 & 119.679 & 886.125 \\
\hline & {$[1.17]$} & {$[1.16]$} & {$[1.03]$} & {$[1.51]$} & [1.17] & {$[1.81]^{*}$} \\
\hline Executives of Non-bank Financial Cos & -17.069 & -13.146 & -106.732 & -6.420 & -0.991 & -71.075 \\
\hline & {$[0.35]$} & {$[0.27]$} & {$[1.68]^{*}$} & {$[0.07]$} & {$[0.01]$} & {$[0.24]$} \\
\hline Financial Executives \& Accountants & 23.054 & 21.396 & 112.679 & 214.156 & 264.817 & 402.142 \\
\hline & {$[0.36]$} & {$[0.34]$} & {$[1.51]$} & {$[1.03]$} & {$[2.29]^{* *}$} & {$[1.53]$} \\
\hline Finance Professors & -28.430 & -27.157 & -102.41 & 206.814 & 22.525 & -264.967 \\
\hline & {$[0.32]$} & {$[0.31]$} & {$[1.53]$} & {$[0.84]$} & {$[0.18]$} & {$[0.79]$} \\
\hline Controls for firm characteristics & yes & yes & yes & yes & yes & yes \\
\hline Controls for board characteristics & yes & yes & yes & yes & yes & yes \\
\hline Controls for deal characteristics & yes & yes & yes & yes & yes & yes \\
\hline Year Fixed Effects & yes & yes & yes & yes & yes & yes \\
\hline Industry Fixed Effects & yes & yes & yes & yes & no & no \\
\hline Firm Fixed Effects & no & no & no & no & yes & yes \\
\hline Observations & 1,288 & 1,288 & 658 & 493 & 658 & 493 \\
\hline $\mathrm{R}^{2}$ & 0.43 & 0.43 & 0.61 & 0.51 & 0.70 & 0.60 \\
\hline
\end{tabular}

Robust $t$-statistics in brackets. * significant at $10 \% ; * *$ significant at $5 \% ; * * *$ significant at $1 \%$. 


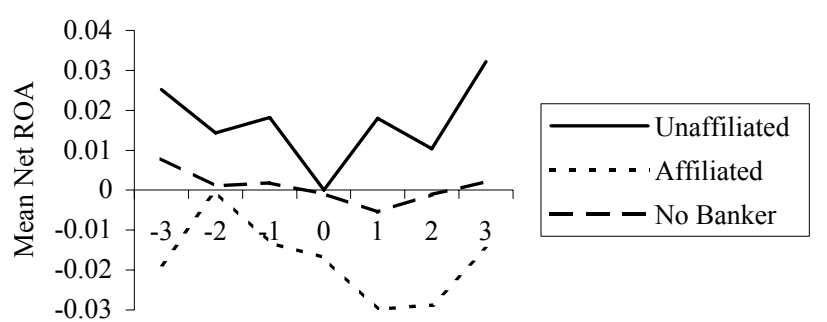

Event year

Loans to Unconstrained Firms

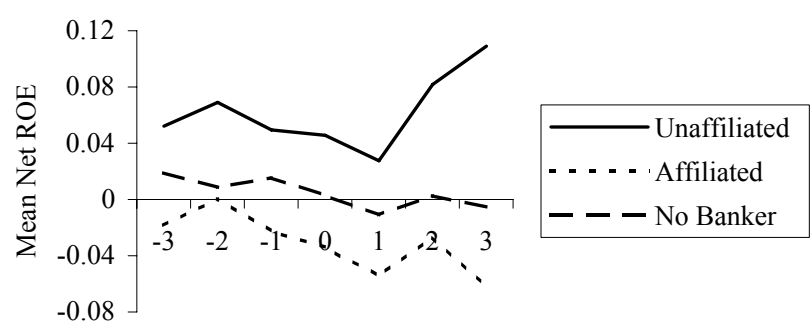

Event year

Loans to Unconstrained Firms

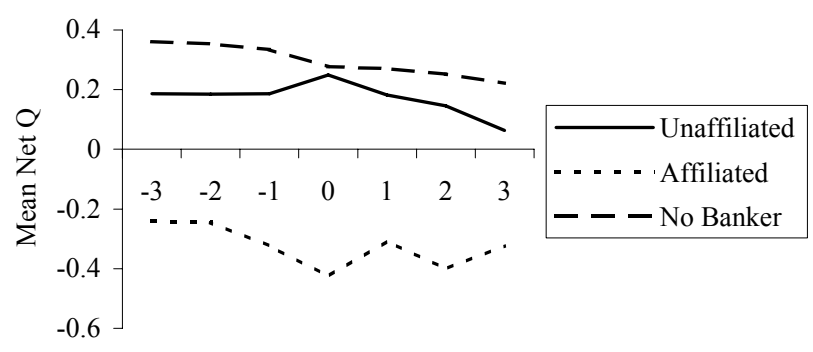

Event year

Loans to Unconstrained Firms

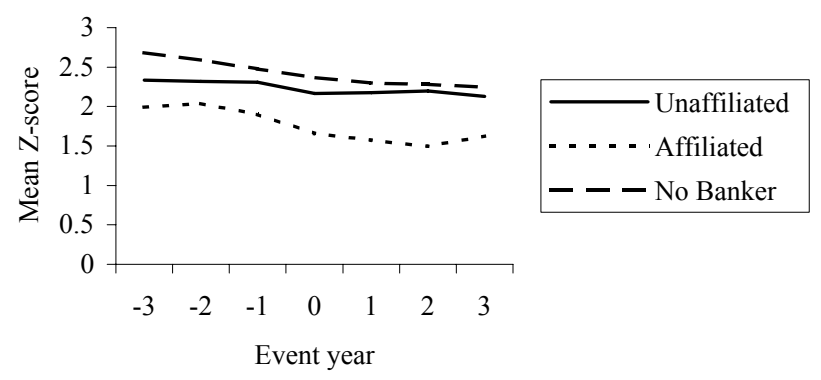

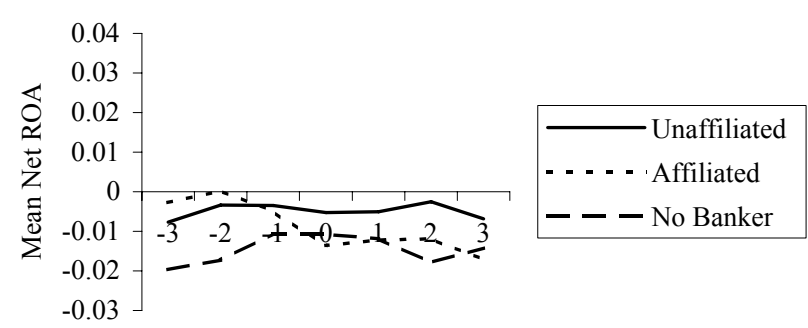

Event year

Loans to Constrained Firms

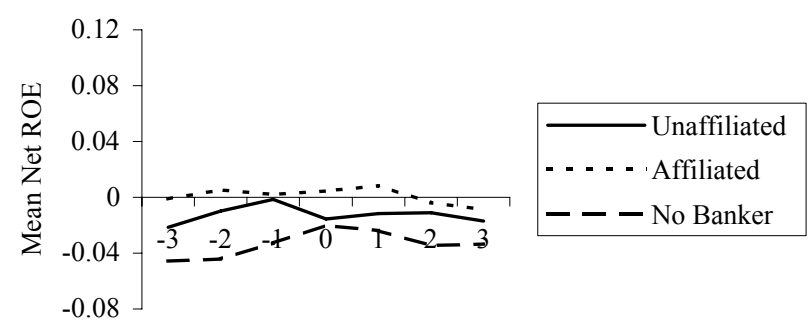

Event year

Loans to Constrained Firms

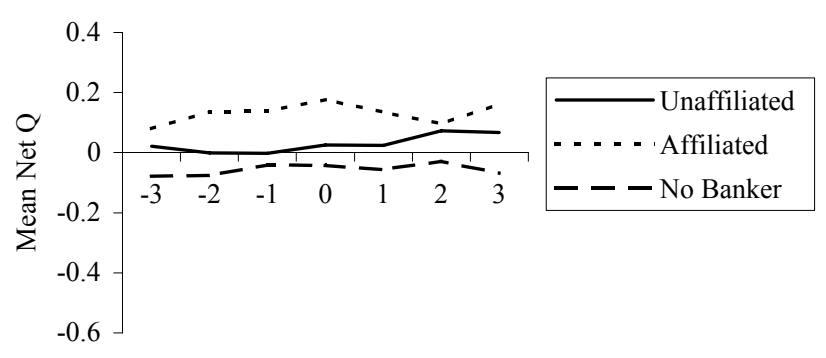

Event year

Loans to Constrained Firms

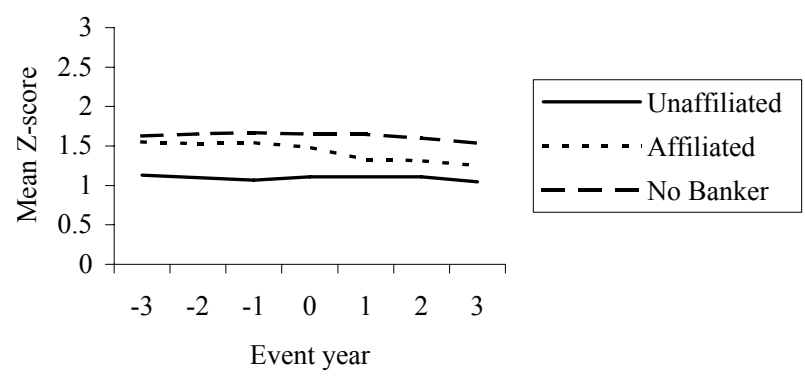

Fig. 2. Firm performance conditional on borrowing. The first six panels depict the sample means of ROA, ROE, and Q net of the full sample industry median. Industry is measured using the Fama and French 48 industry groups. If there are less than five sample firms in a category, the Fama-French 17 group is used; if there are less than five sample firms in this group, the Fama-French 12 group is used. The last two panels depict unadjusted sample mean Altman's Z-scores. ROA is income before extraordinary items plus interest expense plus deferred taxes (when available) plus income tax credit (when available), divided by the average of current and lagged book assets. ROE is net income divided by the average of current and lagged book equity. Z-score is 3.3 times the difference in operating income before depreciation and depreciation and amortization plus sales plus 1.4 times retained earnings plus 1.2 times working capital, divided by book assets. Q is the market value of assets divided by the book value of assets. Constrained (unconstrained) firms are those with lagged Kaplan-Zingales index values above (below) the full sample median. Year 0 indicates the fiscal year in which the firm has obtained at least one bank loan. Affiliated indicates that a commercial banker is present on the board at the time of the loan and that the director's bank is among the loan's originators. Unaffiliated indicates that a commercial banker is present on the board, but his/her bank is not involved in the loan. No banker indicates that no commercial banker sits on the board at the time of the loan. 
Table 7

Acquisitions

Panel A. Summary Statistics

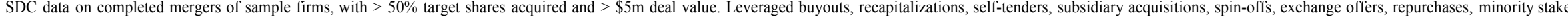

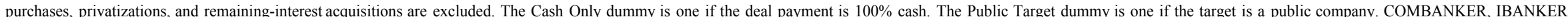

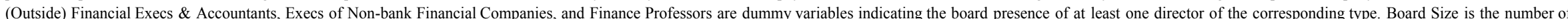

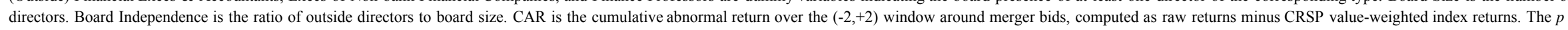
values are from $t$-tests that the differences in means between firms with and without investment banker directors at the time of their merger bids is zero, with standard errors clustered at the industry level (Fama-French 17 industries).

\begin{tabular}{|c|c|c|c|c|c|c|c|c|c|c|c|c|c|}
\hline & \multicolumn{4}{|c|}{ Full Sample } & \multicolumn{4}{|c|}{ Investment Bankers } & \multicolumn{4}{|c|}{ No Investment Bankers } & \multirow[b]{2}{*}{$p$-value } \\
\hline & Obs & Mean & Median & Std Dev & Obs & Mean & Median & Std Dev & $\mathrm{Obs}$ & Mean & Median & Std Dev & \\
\hline$\%$ owned after transaction & 526 & 98.76 & 100 & 7.15 & 83 & 98.59 & 100 & 7.31 & 443 & 98.79 & 100 & 7.12 & 0.76 \\
\hline$\%$ of target acquired & 526 & 96.42 & 100 & 11.65 & 83 & 96.54 & 100 & 11.59 & 443 & 96.40 & 100 & 11.68 & 0.90 \\
\hline Target Value (\$M) & 526 & 214.04 & 128.92 & 227.76 & 83 & 261.62 & 164 & 263.91 & 443 & 205.12 & 122 & 219.52 & 0.05 \\
\hline Cash Only (dummy) & 526 & 0.63 & 1 & 0.48 & 83 & 0.59 & 1 & 0.49 & 443 & 0.63 & 1 & 0.48 & 0.75 \\
\hline Public Target (dummy) & 526 & 0.30 & 0 & 0.46 & 83 & 0.37 & 0 & 0.49 & 443 & 0.29 & 0 & 0.45 & 0.08 \\
\hline IBANKER & 526 & 0.16 & 0 & 0.36 & 83 & 1 & 1 & 0 & 443 & 0 & 0 & 0 & n.a. \\
\hline COMBANKER & 526 & 0.26 & 0 & 0.44 & 83 & 0.34 & 0 & 0.48 & 443 & 0.25 & 0 & 0.43 & 0.42 \\
\hline Executives of Non-bank Financial Cos & 526 & 0.65 & 1 & 0.48 & 83 & 0.64 & 1 & 0.48 & 443 & 0.65 & 1 & 0.48 & 0.86 \\
\hline Finance Executives \& Accountants & 526 & 0.33 & 0 & 0.47 & 83 & 0.23 & 0 & 0.42 & 443 & 0.35 & 0 & 0.48 & 0.20 \\
\hline Outside Finance Executives \& Accountants & 526 & 0.18 & 0 & 0.39 & 83 & 0.06 & 0 & 0.24 & 443 & 0.21 & 0 & 0.41 & 0.00 \\
\hline Finance Professors & 526 & 0.14 & 0 & 0.35 & 83 & 0 & 0 & 0 & 443 & 0.17 & 0 & 0.38 & 0.00 \\
\hline Board Independence & 526 & 0.72 & 0.73 & 0.12 & 83 & 0.76 & 0.78 & 0.11 & 443 & 0.72 & 0.73 & 0.12 & 0.21 \\
\hline Board Size & 526 & 10.98 & 11 & 2.81 & 83 & 12.04 & 12 & 2.45 & 443 & 10.79 & 11 & 2.84 & 0.02 \\
\hline CAR $[-2,+2]$ & 526 & $-0.48 \%$ & $-0.51 \%$ & 0.05 & 83 & $-1.33 \%$ & $-1.41 \%$ & 0.05 & 443 & $-0.32 \%$ & $-0.42 \%$ & 0.05 & 0.11 \\
\hline
\end{tabular}

\section{Panel B. Market Reaction to Merger Bids}

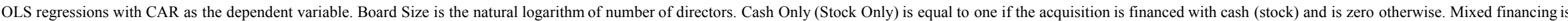

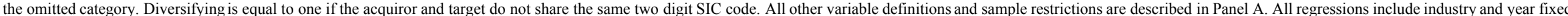

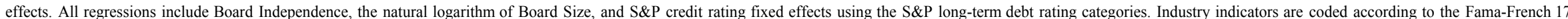
industry groups. All standard errors are clustered by industry.

\begin{tabular}{|c|c|c|c|c|}
\hline & All Bids & All Bids & Public Targets & Private Targets \\
\hline \multirow[t]{2}{*}{ IBANKER } & -0.010 & -0.009 & 0.010 & -0.021 \\
\hline & {$[1.91]^{*}$} & {$[1.71]$} & {$[0.86]$} & {$[2.35]^{* *}$} \\
\hline \multirow{2}{*}{ COMBANKER } & 0.000 & -0.001 & 0.018 & -0.013 \\
\hline & {$[0.02]$} & {$[0.26]$} & [1.29] & {$[1.43]$} \\
\hline \multirow[t]{2}{*}{ Executives of Non-bank Financial Companis } & 0.008 & 0.008 & 0.005 & 0.007 \\
\hline & {$[1.82]^{*}$} & {$[1.76]^{*}$} & {$[0.54]$} & {$[0.59]$} \\
\hline \multirow[t]{2}{*}{ Financial Executives \& Accountants } & 0.004 & 0.003 & -0.007 & 0.010 \\
\hline & {$[1.06]$} & {$[0.75]$} & {$[0.53]$} & {$[2.91]^{* *}$} \\
\hline \multirow{2}{*}{ Finance Professors } & 0.003 & 0.005 & 0.006 & 0.003 \\
\hline & {$[0.93]$} & {$[1.45]$} & {$[0.61]$} & {$[0.25]$} \\
\hline \multirow[t]{2}{*}{ Cash Only } & & -0.003 & 0.011 & -0.011 \\
\hline & & {$[0.36]$} & [1.17] & {$[1.26]$} \\
\hline \multirow[t]{2}{*}{ Stock Only } & & -0.005 & -0.012 & -0.001 \\
\hline & & {$[0.65]$} & {$[1.77]^{*}$} & {$[0.15]$} \\
\hline \multirow[t]{2}{*}{ Diversifying } & & 0.014 & 0.028 & 0.006 \\
\hline & & {$[2.62]^{* *}$} & {$[1.81]^{*}$} & {$[0.51]$} \\
\hline Observations & 526 & 526 & 160 & 248 \\
\hline $\mathrm{R}^{2}$ & 0.08 & 0.09 & 0.28 & 0.16 \\
\hline
\end{tabular}

Robust $t$-statistics in brackets. * significant at $10 \% ; * *$ significant at $5 \% ; * * *$ significant at $1 \%$ 
Raw Buy-and-Hold Returns

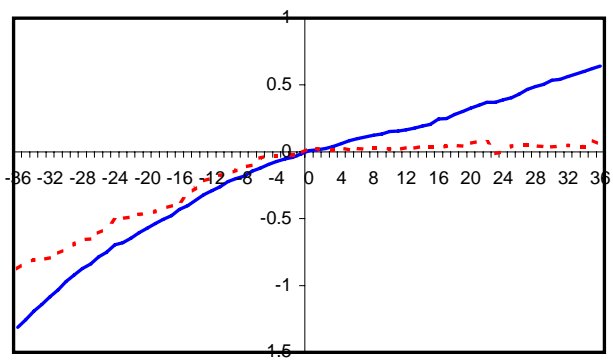

Event Month

\section{Market-Adjusted Buy-and-Hold Returns}

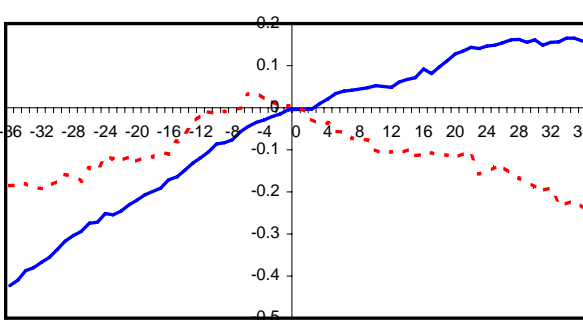

Event Month
- - - - ibanker

Fig. 3. Long-run stock performance around mergers. The figures show stock performance around mergers in event time. Month 0 is the month in which the firm announced a merger bid. The sample includes all completed deals with target shares acquired $>50 \%$ and deal value $>\$ 5 \mathrm{M}$. Leveraged buyouts, recapitalizations, self-tenders, acquisitions of subsidiaries, spin-offs, exchange offers, repurchases, minority stake purchases, privatizations, and acquisitions of remaining interests are excluded. In the legend, "ibanker" indicates that an investment banker is present on the board at the time of the merger bid and "no ibanker" indicates the opposite. All returns are buy-and-hold, i.e., compounded monthly over the relevant interval. For months 0 to 36 , the figures display buy-and-hold returns from month 0 to month $\mathrm{x}$. For months -36 to 0 , the figures display buy-and-hold returns from month -x to 0 , downward shifted so that the cumulative return as of month 0 is zero. In the left figure, monthly raw returns are compounded for each merger event and then averaged across events within the no ibanker and ibanker subsamples. In the right figure, market returns (CRSP value-weighted index) are first subtracted off the monthly raw returns before compounding. 
Table 8

Summary statistics: public debt

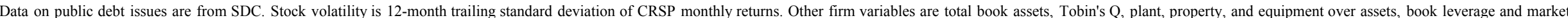

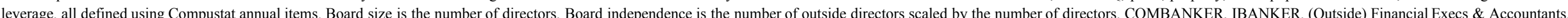

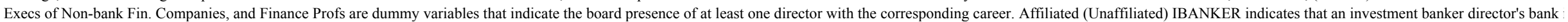

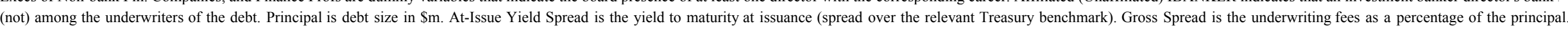

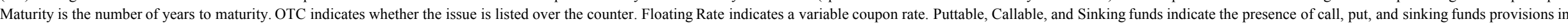

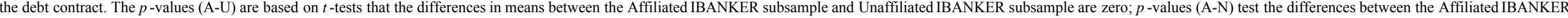
and No IBANKER subsamples. Standard errors are clustered at the firm level.

\begin{tabular}{|c|c|c|c|c|c|c|c|c|c|c|c|c|c|c|}
\hline & \multicolumn{3}{|c|}{ Full Sample } & \multicolumn{3}{|c|}{ Affiliated IBANKER } & \multicolumn{3}{|c|}{ Unaffiliated IBANKER } & \multirow{2}{*}{$\begin{array}{l}p \text {-value } \\
(\mathrm{A}-\mathrm{U})\end{array}$} & \multicolumn{3}{|c|}{ No IBANKER } & \multirow{2}{*}{$\begin{array}{l}p \text {-value } \\
(\mathrm{A}-\mathrm{N})\end{array}$} \\
\hline & Obs & Mean & Std Dev & Obs & Mean & Std Dev & Obs & Mean & Std Dev & & Obs & Mean & Std Dev & \\
\hline \multicolumn{15}{|l|}{ Firm Variables } \\
\hline Assets (\$m) & 4,114 & $38,016.56$ & $56,925.63$ & 202 & $50,143.42$ & $76,247.55$ & 765 & $86,796.97$ & $89,629.05$ & 0.01 & 3,147 & $25,380.20$ & $34,153.52$ & 0.39 \\
\hline Q & 4,114 & 1.43 & 0.73 & 202 & 1.36 & 0.69 & 765 & 1.33 & 0.57 & 0.74 & 3,147 & 1.46 & 0.76 & 0.46 \\
\hline PPE over Assets & 4,114 & 0.38 & 0.23 & 202 & 0.32 & 0.17 & 765 & 0.32 & 0.17 & 0.97 & 3,147 & 0.40 & 0.24 & 0.25 \\
\hline Stock Volatility & 4,114 & 0.08 & 0.03 & 202 & 0.08 & 0.03 & 765 & 0.07 & 0.02 & 0.03 & 3,147 & 0.08 & 0.03 & 0.39 \\
\hline Book Leverage & 4,114 & 0.59 & 0.17 & 202 & 0.60 & 0.21 & 765 & 0.65 & 0.17 & 0.15 & 3,147 & 0.58 & 0.17 & 0.76 \\
\hline Market Leverage & 4,114 & 0.30 & 0.13 & 202 & 0.32 & 0.17 & 765 & 0.33 & 0.15 & 0.73 & 3,147 & 0.29 & 0.12 & 0.58 \\
\hline Board Size & 4,114 & 12.22 & 2.19 & 202 & 12.37 & 2.33 & 765 & 13.19 & 2.22 & 0.01 & 3,147 & 11.97 & 2.10 & 0.53 \\
\hline Board Independence & 4,114 & 0.80 & 0.12 & 202 & 0.75 & 0.15 & 765 & 0.79 & 0.15 & 0.05 & 3,147 & 0.81 & 0.11 & 0.26 \\
\hline IBANKER & 4,114 & 0.24 & 0.42 & 202 & 1 & 0 & 765 & 1 & 0 & n.a. & 3,147 & 0 & 0 & n.a. \\
\hline Affiliated & 4,114 & 0.05 & 0.22 & 202 & 1 & 0 & 765 & 0 & 0 & n.a. & 3,147 & 0 & 0 & n.a. \\
\hline Unaffiliated & 4,114 & 0.19 & 0.39 & 202 & 0 & 0 & 765 & 1 & 0 & n.a. & 3,147 & 0 & 0 & n.a. \\
\hline COMBANKER & 4,114 & 0.26 & 0.44 & 202 & 0.27 & 0.44 & 765 & 0.48 & 0.50 & 0.02 & 3,147 & 0.21 & 0.41 & 0.74 \\
\hline Execs of Non-bank Fin Cos & 4,114 & 0.52 & 0.50 & 202 & 0.30 & 0.46 & 765 & 0.34 & 0.47 & 0.72 & 3,147 & 0.57 & 0.49 & 0.06 \\
\hline Fin Execs \& Accountants & 4,114 & 0.32 & 0.47 & 202 & 0.50 & 0.50 & 765 & 0.44 & 0.50 & 0.64 & 3,147 & 0.28 & 0.45 & 0.18 \\
\hline Outside Fin Execs \& Accountants & 4,114 & 0.20 & 0.40 & 202 & 0.33 & 0.47 & 765 & 0.22 & 0.41 & 0.25 & 3,147 & 0.19 & 0.39 & 0.41 \\
\hline Finance Professors & 4,114 & 0.12 & 0.32 & 202 & 0.13 & 0.34 & 765 & 0.05 & 0.23 & 0.47 & 3,147 & 0.13 & 0.34 & 0.98 \\
\hline \multicolumn{15}{|l|}{ Debt Variables } \\
\hline Principal (\$m) & 4,114 & 107.00 & 171.12 & 202 & 176.47 & 197.64 & 765 & 114.33 & 211.15 & 0.24 & 3,147 & 100.76 & 156.84 & 0.18 \\
\hline Principal / Firm Value & 4,114 & 0.01 & 0.02 & 202 & 0.01 & 0.03 & 765 & 0.01 & 0.01 & 0.06 & 3,147 & 0.01 & 0.02 & 0.41 \\
\hline Gross Spread & 2,258 & 0.58 & 0.39 & 125 & 0.59 & 0.38 & 386 & 0.48 & 0.32 & 0.01 & 1,747 & 0.60 & 0.40 & 0.86 \\
\hline At-Issue Yield Spread & 2,194 & 103.21 & 75.87 & 104 & 116.74 & 64.65 & 354 & 95.20 & 76.41 & 0.05 & 1,736 & 104.03 & 76.25 & 0.38 \\
\hline Maturity & 4,114 & 8.36 & 8.30 & 202 & 7.29 & 7.97 & 765 & 5.98 & 6.74 & 0.41 & 3,147 & 9.01 & 8.55 & 0.34 \\
\hline OTC & 4,114 & 0.00 & 0.05 & 202 & 0 & 0 & 765 & 0.00 & 0.04 & 0.32 & 3,147 & 0.00 & 0.06 & 0.17 \\
\hline Floating Rate & 4,114 & 0.14 & 0.34 & 202 & 0.15 & 0.36 & 765 & 0.24 & 0.43 & 0.00 & 3,147 & 0.11 & 0.31 & 0.41 \\
\hline Puttable & 4,114 & 0.04 & 0.19 & 202 & 0.04 & 0.20 & 765 & 0.04 & 0.19 & 0.98 & 3,147 & 0.04 & 0.19 & 0.96 \\
\hline Callable (Make Whole Call) & 4,114 & 0.07 & 0.25 & 202 & 0.07 & 0.25 & 765 & 0.03 & 0.17 & 0.16 & 3,147 & 0.08 & 0.27 & 0.81 \\
\hline Sinking Funds & 4,114 & 0.02 & 0.15 & 202 & 0.01 & 0.10 & 765 & 0.02 & 0.15 & 0.57 & 3,147 & 0.02 & 0.15 & 0.28 \\
\hline
\end{tabular}


Table 9

Cost and size of public debt issues

OLS regressions with dependent variables Principal (debt issued in \$m) in Columns I and II and Gross Spread (underwriter fees as a percentage of the issue) in Column III. Indicators for put, call, and sinking fund covenants, and variable coupon rates are included in all estimations, but not shown in the table. Q is the market value of assets over the book value of assets. Firm Size is the natural logarithm of total book assets. Board Size is the natural logarithm of number of directors on the board. Board Independence is the ratio of outside directors to board size. PPE/Assets is plants, property, and equipment scaled by assets. Leverage is long-term debt plus debt in current liabilities, divided by long-term debt plus debt in current liabilities plus stockholders' equity. Stock Volatility is measured over the 12 months preceding the debt issue. Maturity is the natural logarithm of the days to maturity. COMBANKER is an indicator variable for the presence of a commercial banker on the board; IBANKER indicates an investment banker; Executivess of Non-bank Financial Companies, Financial Executives \& Accountants, and Finance Professors are dummy variables indicating the presence of such a director on the board. Affiliated IBANKER indicates that the investment banker director's bank is among the underwriters of the issue. Unaffiliated IBANKER indicates that an investment banker is present on the board, but his/her bank is not involved in the issue. All regressions include industry and year fixed effects as well as S\&P credit rating fixed effects, using the S\&P long-term debt rating categories. Industry indicators are coded according to the Fama-French 17 industry groups. All standard errors are clustered by firm.

\begin{tabular}{|c|c|c|c|}
\hline Dependent Variable & $\begin{array}{c}\text { (I) } \\
\text { Principal } \\
(\$ \mathrm{~m}) \\
\end{array}$ & $\begin{array}{c}\text { (II) } \\
\text { Principal } \\
(\$ \mathrm{~m}) \\
\end{array}$ & $\begin{array}{c}\text { (III) } \\
\text { Gross Spread }\end{array}$ \\
\hline IBANKER & $\begin{array}{l}20.144 \\
{[1.81]^{*}}\end{array}$ & & \\
\hline Affiliated IBANKER & & $\begin{array}{c}64.822 \\
{[1.69]^{*}}\end{array}$ & $\begin{array}{l}-0.007 \\
{[0.18]}\end{array}$ \\
\hline Unaffiliated IBANKER & & $\begin{array}{l}4.720 \\
{[0.36]}\end{array}$ & $\begin{array}{c}-0.063 \\
{[2.29]^{* *}}\end{array}$ \\
\hline COMBANKER & $\begin{array}{l}8.869 \\
{[0.74]}\end{array}$ & $\begin{array}{l}10.524 \\
{[0.85]}\end{array}$ & $\begin{array}{c}0.041 \\
{[1.69]^{*}}\end{array}$ \\
\hline Executives of Non-bank Financial Companies & $\begin{array}{l}1.201 \\
{[0.11]}\end{array}$ & $\begin{array}{l}1.606 \\
{[0.15]}\end{array}$ & $\begin{array}{l}0.033 \\
{[1.63]}\end{array}$ \\
\hline Financial Executives \& Accountants & $\begin{array}{l}9.649 \\
{[0.95]}\end{array}$ & $\begin{array}{l}9.488 \\
{[0.93]}\end{array}$ & $\begin{array}{l}0.029 \\
{[1.55]}\end{array}$ \\
\hline Finance Professors & $\begin{array}{l}4.548 \\
{[0.27]}\end{array}$ & $\begin{array}{l}3.645 \\
{[0.21]}\end{array}$ & $\begin{array}{c}-0.051 \\
{[2.08]^{* *}}\end{array}$ \\
\hline Q & $\begin{array}{l}17.730 \\
{[1.88]^{*}}\end{array}$ & $\begin{array}{l}18.280 \\
{[1.92]^{*}}\end{array}$ & $\begin{array}{l}-0.027 \\
{[1.37]}\end{array}$ \\
\hline PPE/Assets & $\begin{array}{c}-57.395 \\
{[1.30]}\end{array}$ & $\begin{array}{c}-60.696 \\
{[1.39]}\end{array}$ & $\begin{array}{l}-0.122 \\
{[1.41]}\end{array}$ \\
\hline Stock Volatility & $\begin{array}{c}291.26 \\
{[2.13]^{* *}}\end{array}$ & $\begin{array}{c}256.331 \\
{[1.85]^{*}}\end{array}$ & $\begin{array}{c}1.552 \\
{[2.94]^{* * *}}\end{array}$ \\
\hline OTC & $\begin{array}{l}-2.439 \\
{[0.06]}\end{array}$ & $\begin{array}{c}0.019 \\
{[0.00]}\end{array}$ & $\begin{array}{c}0.261 \\
{[1.73]^{*}}\end{array}$ \\
\hline Leverage & $\begin{array}{l}-178.011 \\
{[3.48]^{* * *}}\end{array}$ & $\begin{array}{l}-169.661 \\
{[3.16]^{* * *}}\end{array}$ & $\begin{array}{l}0.087 \\
{[1.22]}\end{array}$ \\
\hline Firm Size & $\begin{array}{c}53.274 \\
{[6.08]^{* * *}}\end{array}$ & $\begin{array}{c}53.555 \\
{[6.01]^{* * *}}\end{array}$ & $\begin{array}{c}-0.052 \\
{[4.06]^{* * *}}\end{array}$ \\
\hline Maturity & $\begin{array}{c}38.909 \\
{[4.71]^{* * *}}\end{array}$ & $\begin{array}{c}38.298 \\
{[4.82]^{* * *}}\end{array}$ & $\begin{array}{c}0.073 \\
{[4.69]^{* * *}}\end{array}$ \\
\hline Principal (log) & & & $\begin{array}{c}0.028 \\
{[2.54]^{* *}}\end{array}$ \\
\hline Board Size & $\begin{array}{c}-51.815 \\
{[0.97]}\end{array}$ & $\begin{array}{c}-51.163 \\
{[0.96]}\end{array}$ & $\begin{array}{l}-0.021 \\
{[0.37]}\end{array}$ \\
\hline Board Independence & $\begin{array}{l}-148.903 \\
{[2.97]^{* * *}}\end{array}$ & $\begin{array}{l}-145.326 \\
{[2.85]^{* * *}}\end{array}$ & $\begin{array}{c}0.25 \\
{[2.32]^{* *}}\end{array}$ \\
\hline Observations & 4,114 & 4,114 & 2,258 \\
\hline $\mathrm{R}^{2}$ & 0.34 & 0.34 & 0.45 \\
\hline
\end{tabular}

Robust $t$-statistics in brackets. * significant at $10 \% ; * *$ significant at $5 \% ; * * *$ significant at $1 \%$. 
Table 10

Financial experts and executive compensation

OLS regressions with the following dependent variable: an indicator equal to one if the CEO receives any option grant in Column I; the natural logarithm of one plus the Black-Scholes value of option grants in Column II; the change in the natural logarithm of one plus total compensation in Column III; and the change in the natural logarithm of one plus cash compensation in Column IV. Compensation data is from the Hall-Liebman (1998) for 1988 to 1994 and from ExecuComp from 1995 forward. All regressions include a dummy variable which takes the value one in the Execucomp sample years. $\mathrm{R}$ is common stock returns over the fiscal year. Colun I includes controls for Board Independence, Board Size, and their interactions with $\mathrm{R}_{t}$ and $\mathrm{R}_{\mathrm{t}-1}$, as well as controls for Firm Size, CEO Age, CEO Tenure, year fixed effects and firm fixed effects. Financial expertise variables are dummies which take the value one when a director of the type in question is present. Board Size is the natural logarithm of number of directors on the board. Board Independence is the ratio of outsiders to board size. Firm Size is the natural logarithm of assets at the beginning of the year. Columns III and IV also include the interactions of Board Independence and Board Size with Rand $\mathrm{R}_{\mathrm{t}-1}$.

\begin{tabular}{|c|c|c|c|c|}
\hline Dependent Variable & $\begin{array}{c}\text { (I) } \\
\text { Any Options }\end{array}$ & $\begin{array}{c}\text { (II) } \\
\ln (1+\mathrm{BSV})\end{array}$ & $\begin{array}{c}(\mathrm{III}) \\
\Delta \ln (1+\text { Total Comp }) \\
\end{array}$ & $\begin{array}{c}(\mathrm{IV}) \\
\Delta \ln (1+\text { Cash Comp }) \\
\end{array}$ \\
\hline \multirow[t]{2}{*}{$\mathrm{R}_{\mathrm{t}}$} & 0.022 & 0.486 & 1.224 & 0.136 \\
\hline & $(0.95)$ & $(2.47)^{* *}$ & $(1.50)$ & $(0.50)$ \\
\hline \multirow[t]{2}{*}{$\mathrm{R}_{\mathrm{t}-1}$} & 0.005 & 0.073 & -0.454 & -0.018 \\
\hline & $(0.84)$ & $(2.73)^{* * *}$ & $(0.65)$ & $(0.07)$ \\
\hline \multirow[t]{2}{*}{ Finance Professors } & 0.081 & 0.432 & 0.026 & 0.116 \\
\hline & $(1.86)^{*}$ & $(1.41)$ & $(0.27)$ & $(2.14)^{* *}$ \\
\hline \multirow[t]{2}{*}{ (Finance Professors) $* \mathrm{R}_{\mathrm{t}-1}$} & & & -0.689 & -0.380 \\
\hline & & & $(1.95)^{*}$ & $(1.72)^{*}$ \\
\hline \multirow[t]{2}{*}{ (Finance Professors) $* \mathrm{R}_{\mathrm{t}}$} & & & 0.056 & -0.308 \\
\hline & & & $(0.31)$ & $(2.07)^{* *}$ \\
\hline \multirow[t]{2}{*}{ Fin Execs \& Accountants } & -0.010 & -0.064 & 0.054 & -0.033 \\
\hline & $(0.45)$ & $(0.42)$ & $(0.76)$ & $(0.99)$ \\
\hline \multirow[t]{2}{*}{ (Fin Execs \& Accountants) $* \mathrm{R}_{\mathrm{t}-1}$} & & & -0.078 & 0.016 \\
\hline & & & $(0.49)$ & $(0.20)$ \\
\hline \multirow[t]{2}{*}{ (Fin Execs \& Accountants) $* \mathrm{R}_{\mathrm{t}}$} & & & 0.110 & -0.033 \\
\hline & & & $(0.61)$ & $(0.44)$ \\
\hline \multirow[t]{2}{*}{ COMBANKER } & 0.034 & 0.199 & 0.035 & 0.033 \\
\hline & $(0.94)$ & $(0.76)$ & $(0.42)$ & $(1.22)$ \\
\hline \multirow[t]{2}{*}{$(\mathrm{COMBANKER}) * \mathrm{R}_{\mathrm{t}-1}$} & & & 0.094 & 0.033 \\
\hline & & & $(0.34)$ & $(0.38)$ \\
\hline \multirow[t]{2}{*}{$(\mathrm{COMBANKER}) * \mathrm{R}_{\mathrm{t}}$} & & & 0.080 & -0.006 \\
\hline & & & $(0.35)$ & $(0.10)$ \\
\hline \multirow[t]{2}{*}{ IBANKER } & 0.029 & 0.12 & -0.061 & 0.049 \\
\hline & $(0.77)$ & $(0.50)$ & $(0.63)$ & $(1.74)^{*}$ \\
\hline \multirow[t]{2}{*}{$\left(\right.$ IBANKER) $* \mathrm{R}_{\mathrm{t}-1}$} & & & -0.229 & -0.021 \\
\hline & & & $(0.93)$ & $(0.38)$ \\
\hline \multirow[t]{2}{*}{$(\mathrm{IBANKER}) * \mathrm{R}_{\mathrm{t}}$} & & & 0.113 & -0.132 \\
\hline & & & $(0.53)$ & $(1.73)^{*}$ \\
\hline \multirow[t]{2}{*}{ Execs of Non-bank Fin Cos } & 0.038 & 0.25 & 0.006 & 0.004 \\
\hline & $(1.44)$ & $(1.44)$ & $(0.09)$ & $(0.21)$ \\
\hline \multirow[t]{2}{*}{$\left(\right.$ Execs of Non-bank Fin Cos) $* \mathrm{R}_{\mathrm{t}-1}$} & & & -0.383 & 0.028 \\
\hline & & & $(1.58)$ & $(0.36)$ \\
\hline \multirow[t]{2}{*}{$\left(\right.$ Execs of Non-bank Fin Cos) $* \mathrm{R}_{\mathrm{t}}$} & & & 0.109 & 0.017 \\
\hline & & & $(0.73)$ & $(0.25)$ \\
\hline Additional Controls (see Caption) & yes & yes & yes & yes \\
\hline Observations & 2,909 & 2,909 & 2,471 & 2,487 \\
\hline $\mathrm{R}^{2}$ & 0.10 & 0.18 & 0.09 & 0.14 \\
\hline
\end{tabular}

Constant included. $t$-statistics (in parentheses) are heteroskedasticity-corrected and clustered by firm.

* significant at $10 \%$; * significant at $5 \% ; * *$ significant at $1 \%$. 